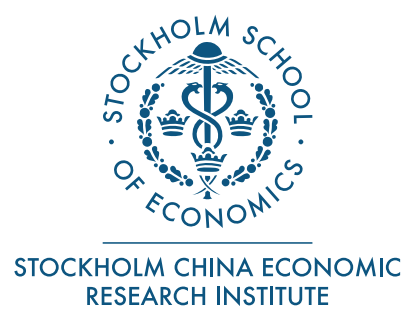

\title{
Mixing Business with Politics: Political Participation by Entrepreneurs in China
}

\author{
Xunan Feng \\ Shanghai University \\ Anders C. Johansson \\ Stockholm School of Economics \\ Tianyu Zhang \\ Chinese University of Hong Kong
}

Stockholm School of Economics Asia Working Paper

No. 28

December 2013 


\title{
Mixing Business with Politics: Political Participation by Entrepreneurs in China
}

\author{
Xunan Feng \\ Shanghai University \\ Anders C. Johansson ${ }^{1}$ \\ Stockholm School of Economics \\ Tianyu Zhang \\ Chinese University of Hong Kong
}

December 2013

\footnotetext{
${ }^{1}$ Corresponding author, Stockholm School of Economics, P.O. Box 6501, SE-113 83 Stockholm, Sweden. Phone: +46-8-736 9367. Fax: +46-8-31 30 17. Email: anders.johansson@hhs.se. Anders C. Johansson acknowledges financial support from the Ragnar Söderberg Foundation. Xunan Feng acknowledges financial support from National Natural Science Foundation of China (71302049) and Shanghai College Foundation for Excellent Young Teachers of China (37-0129-12-002). We thank seminar participants at Stockholm School of Economics and University of Gothenburg for helpful comments.
} 


\title{
Mixing Business with Politics: Political Participation by Entrepreneurs in China
}

\begin{abstract}
We study how Chinese private entrepreneurs benefit from participating in politics. Using original hand-collected data on listed firms controlled by private entrepreneurs, we document a significant positive relationship between political participation and change in firm performance. We also provide evidence that the change in social status cannot explain the change in performance. We then identify several ways through which firms gain preferential treatment when the controlling entrepreneur participates in politics: better access to debt financing, preferential tax treatment, more government subsidies, and superior access to regulated industries.
\end{abstract}

JEL Classification: G30; G32; G34; H20; P26

Keywords: Political participation; Entrepreneurs; Corporate governance; Rent seeking; Debt financing; Tax burden; Government subsidies; Mergers and acquisitions; Regulated industries; China 


\section{Introduction}

This paper investigates the economic consequences of mixing politics and business, particularly the channels through which political participation facilitates business. Business leaders are invited to participate in politics due to their expertise and in the name of the common good. However, the political capital derived from political participation can also be utilized by businessmen for their own benefit. Previous studies have shown that political relations can bring benefit to entrepreneurs and their firms (Fisman, 2001; Johnsson and Mitton, 2003; Faccio, 2006; Faccio et al., 2006; and Claessens et al., 2008). In these studies, benefits are channeled to the firm through a specifically established connection. We will show in this paper that entrepreneurs may actually gain access to political capital by means of a onetime participation in politics. This act of political participation does not guarantee the participant political power, but creates an opportunity to interact with politicians. We further show several channels through which the entrepreneur benefits from the political capital he or she has derived from political participation. Potentially important channels for preferential treatment include better access to debt financing, preferential tax treatment, more government subsidies, and superior access to regulated industries through corporate deals.

China is especially well suited for our study. Chinese private entrepreneurs have only had the opportunity to participate in politics for a relatively short time period. This opportunity increased considerably after former President Jiang Zemin welcomed business leaders into the 
Chinese Communist Party (CCP) in 2001. In a business environment marked by poor legal protection, ambiguous property rights, and rent seeking, many Chinese private entrepreneurs have tried to develop close ties to local and national politicians (Shambaugh, 2009; Wright, 2010). Political participation does not guarantee the establishment of a specific political connection, but it allows an opportunity to interact with politicians. Since entrepreneurs are purportedly invited to participate in politics for the common good and democracy, the public deserves a systematic analysis of whether these entrepreneurs are seeking private benefits in the process. The answer is unclear ex ante. On the one hand, engagement in public affairs will distract the entrepreneur from operating his or her own business, which should result in firm underperformance. On the other hand, political participation may help the entrepreneur to build up his or her political capital, which in turn will contribute to firm performance. However, such political capital may not necessarily turn out to be as solid as that derived from a specific political connection, but may instead be relatively weak. It is therefore important to investigate the actual economic consequences of such political participation and, in particular, whether and how private entrepreneurs receive private benefits even though political participation is in the name of the common good and democracy. ${ }^{2}$

\footnotetext{
${ }^{2}$ Theoretically, all members in NPC and CPPCC are selected through democratic elections in a process that follows the Constitution of the People's Republic of China, the Electoral Law of the National People's Congress
} 
The key event of our study, the initiation of political participation, is defined by an entrepreneur (or one of his or her family members) becoming a member of the National People's Congress (NPC) or the Chinese People's Political Consultative Conference (CPPCC) at the national or provincial level. Our hand-collected data set covers all listed entrepreneurial firms between 1993 and 2011. Using this, we identify 86 cases of listed firms controlled by private entrepreneurs who begin to participate in high-level politics in 1998, 2003, or 2008. We compare the change in performance after these events with all the remaining privately controlled firms in the same year as a control group. We find that political participation has a significant positive effect on long-run stock performance and operating performance. When exploring potential channels of performance enhancement, we document that political participation facilitates debt financing as shown by higher leverage and longer maturity in debt for firms after their controlling owner begins to participate in politics. Political participation also reduces firms' tax burden (measured as the effective tax rate) and increases the amount of government subsidies granted to firms. Finally, political participation facilitates access to regulated industries through merger and acquisitions (M\&As). Overall, our empirical findings shed light on a number of benefits that stem from political participation by private entrepreneurs in China. These results have important implications for our understanding of 
political participation as crucial factor for doing business in China. The findings in this paper explain why business owners in emerging economies may seek the opportunity to participate in national politics.

This study relates to research that focuses on rent seeking and how entrepreneurs use political ties to benefit their business. In a seminal article, Krueger (1974) argues that it is natural for firms to devote economic resources toward rent seeking in order to compete for favorable treatment. In general, politicians are able to influence firms through a variety of policy decisions. Politicians may do this for political as well as personal objectives (e.g., La Porta et al., 2002; Rajan and Zingales, 2003). Government decisions can have a significant effect on firm performance through various channels, such as preferential access to finance, better access to different forms of government subsidies, tax benefits, and reduced regulatory constraints.

Our paper contributes to the literature in several ways. First, our setting allows us to carry out an event analysis by comparing the change in performance, which is a variation of the difference-in-difference method (DiD), therefore alleviating serious endogeneity issues found in earlier related studies. Research focusing on the economic value of political connections of U.S. firms and Non-U.S firms ${ }^{3}$ is subject to potentially serious endogeneity

\footnotetext{
${ }^{3}$ For studies focusing on the U.S., see Roberts (1990), Kroszner and Stratmann (1998), Jayachandran, (2006), Knight (2006), Benmelech and Moskowitz (2007), Goldman et al. (2009), and Cooper et al., 2010. For studies on
} 
problems due to the data used. For example, unobservable factors such as innate business competence may explain the existence of political connections as well as superior performance. Our analysis, which applies a change model, avoids such issues because we are able to fix all the fundamental issues related to the firms around the event. Event studies related to the establishment or elimination of political connections, such as Faccio (2006) and Fisman (2001), can avoid the endogeneity issues. However, these studies only focus on shortterm effects. Our study investigates a window extending up to three years after the event. Second, we contribute to the literature by systematically identifying the channels through which political participation enhances firm performance. Earlier studies have focused on finding evidence of effects on value and performance. Only a limited number of more recent studies have attempted to identify potential rent-seeking channels. The channel that has arguably been analyzed most thoroughly is that of preferential access to financing (e.g. Charumilind, 2006; Dinc, 2005; Faccio et al., 2006; Johnson and Mitton, 2003; Khwaja and Mian, 2005). While these studies on political connections and rent-seeking channels are important, our study provides a considerably more comprehensive understanding of potential preferential treatment for selected business owners and their firms. In addition to analyzing political participation and access debt financing, we are able to identify several other channels 
that entrepreneurs in China exploit through political participation, including increased tax benefits and government subsidies as well as beneficial M\&A deals, most of which have not been explored rigorously in previous studies.

Third, our analysis touches upon an alternative growth channel for Chinese privately controlled firms. Allen et al. (2005) argue that alternative channels, including mechanisms centering on relationships, have been driving the higher growth in the private sector during the last decades. Our results show that political participation facilitates the use of such alternative channels. Fourth, our study reveals important side effects of China's current political system. Fifth, this paper contributes to the literature on networks in finance (e.g. Allen and Babus, 2009). Finally, we believe that it is important to distinguish between the value of political connections and effects of political participation ${ }^{4}$, which represents an explicit commitment and direct involvement in a country's political process, especially in transition and developing economies, where entrepreneurs are often motivated to participate in politics (e.g. Li et al., 2006).

\footnotetext{
${ }^{4}$ In previous research on China, political connections have often been identified by looking at the background of the CEO or Board Director. For example, Fan et al. (2007) find that such connections can hurt the value of stateowned enterprises (SOEs). Political participation, on the other hand, means that business owners actively participate in politics. In other words, political participation can be seen as a direct result of an act by the business owner.
} 
The remainder of this paper proceeds as follows. Section 2 discusses the institutional background and political participation by private entrepreneurs in China. It also develops an hypotheses for the empirical analysis. Section 3 introduces the data sample, while Section 4 presents the initial empirical results of the effects on stock performance and operating performance. Building on these results, Section 5 then analyzes different channels for potential preferential treatment. Section 6 presents the results of additional robustness tests. Finally, Section 7 concludes the paper.

\section{Institutional Background and Hypotheses}

\subsection{Private Entrepreneurs and Politics in China}

Private entrepreneurs did not constitute an important part of early economic reforms in China. Between 1978 and 1988, the first form of private enterprises that was allowed, the socalled getihu, was restricted to have no more than eight employees. At that time, private entrepreneurs basically played a limited role in an experiment in which the Chinese government tried to come to grips with how private businesses could function alongside stateowned enterprises (SOEs). As a result, early private entrepreneurs were only allowed to do business in sectors that usually did not interest SOEs. In 1988, as the private sector became increasingly important for the Chinese economy, private firms with more than eight employees (siying qiye) were allowed. During the second half of the 1980s, things seemed to progress fast 
for the private sector. However, after the Tiananmen demonstrations in 1989, private entrepreneurs experienced a negative setback in the treatment by the government. The CCP imposed a formal ban stating that private entrepreneurs were not allowed in the party. Private entrepreneurs had been discriminated against by the state and its different entities before, but after 1989, they had to function in a more difficult business environment.

Albeit discriminatory practices were more or less the norm when dealing with private enterprises, the private sector boomed during the 1990s. Deng Xiaoping's so-called Southern Tour (nanxun) in 1992 also marked a change in the treatment of private entrepreneurs. A wave of new economic reforms came to change the role that entrepreneurs played in the domestic economy. For example, the Chinese Company Law was established in 1994 as a first serious attempt to clarify the functions of both state-owned and private enterprises. In the mid-1990s, the restructuring (gaizhi) of the previously so important township and village enterprises (TVEs) had begun, a process that soon accelerated. A major change in how the Chinese regime perceived the private sector was seen in 1999 , when it was stated that "individual, private and other non-public economies that exist within the limits prescribed by law are major components of the socialist market economy" (Tsai, 2006). In 2001, President Jiang Zemin declared that private entrepreneurs should be allowed to join the CCP. This was reiterated formally during the 16th Party Congress in the following year, and showed how important the private sector had become for the Chinese economy. In 2005, there were approximately 30 million registered private companies in China. In the same year, they accounted for 
approximately half of China's total GDP (Tsai, 2007). Dougherty et al. (2007) find that the private sector increased in importance quite considerably at the turn of the century. Using a data sample comprised of approximately 250,000 companies, they show that private firms' share of total industrial product increased from $25 \%$ in 1998 to over $50 \%$ in 2003 . It was this change that Jiang Zemin acknowledged: private firms with their much higher average productivity compared to SOEs, was driving China's economic growth.

Despite increased acceptance by the Party, private entrepreneurs have been discriminated against during most of the reform period. Entrepreneurs that tried to build up their business during the early period of the economic reforms had to rely on creative solutions to overcome such discrimination. For example, a large number of private enterprises called "red-hat" (dai hongmaozi) firms registered as publicly-owned firms to disguise their true ownership (Tsai, 2007). It is not difficult to surmise that many private entrepreneurs have chosen to get involved in politics or become members of the CCP at least partly to ensure better treatment by local and state officials.

Entrepreneurs that become members of the CCP are often called "red capitalists" (Dickson, 2003). In this study, however, we focus on entrepreneurs that not only become passive members of the $\mathrm{CCP}$, but also choose to participate actively in politics at the highest levels. It should be noted that while the number of private entrepreneurs who participate in politics is growing fast, it does not necessarily mean that all of them constitute private entrepreneurs who decide to become members of the CCP or become more politically active. 
For example, if we were to define a private entrepreneur who begins to participate in politics as a person who is merely a member of the CCP, then most such individuals were members of the party before they became entrepreneurs (Dickson, 2008). After the decision to formally accept private entrepreneurs as party members in 2002, people inside the CCP quickly became more active in a plethora of private business ventures. As an increasing number of people from the CCP became involved in private businesses, a move that has been called to "jump into the sea" (xia hai) since the early $1990 \mathrm{~s}$, the private sector has grown even faster. While members of this group of private entrepreneurs are of interest in their own right, this study focuses exclusively on the private entrepreneurs that begin to participate in politics by becoming a member of a major political body at the provincial or national level, not the other way around.

\subsection{Defining Political Participation}

As mentioned earlier, this study focuses on entrepreneurs who begin to participate in politics while already being in control of a publicly traded company. Political participation is identified for either the private entrepreneur who controls the company or one of his or her family members ${ }^{5}$. Chen et al. (2009) find that Chinese listed firms are typically controlled by one dominant shareholder, who holds a significantly larger ownership share than the company's other shareholders. Similarly, Feng et al. (2011) identify ownership by focusing on the ultimate shareholder in Chinese listed firms. Following these studies, we use the ultimate

\footnotetext{
${ }^{5}$ We include the wife/husband, father and mother, as well as the children of the ultimate shareholder.
} 
shareholder to identify privately controlled firms. We then use representation at one of two key political bodies as a proxy for political participation: the National People's Congress (NPC), and the Chinese People's Political Consultative Conference (CPPCC). We include participation at the provincial and national levels in one of these entities. The act of political participation is thus defined as active participation at the highest political levels in China. Wright (2010) argues that private entrepreneurs have shown considerable interest in joining these political bodies and we believe that a position in one of them constitutes a clear signal of political participation. ${ }^{6}$

The NPC and the CPPCC, commonly referred to as liang hui, or the "Two Sessions", constitute China's largest political events. The NPC functions as the country's legislative body and is formally the highest organ of the state, while the CPPCC functions as a political advisory body made up of members from different parties and organizations as well as individuals. The CPPCC has been used by the Chinese Communist Party (CCP) to attract nonParty members to the political arena and to increase the support of the Party. Shambaugh (2009) also argues that the CPPCC is becoming more systematically involved in the Party's policymaking process. Members of both the NPC and the CPPCC are approved by the CCP, demonstrating the Party's influence in these entities. It is widely recognized that the inclusion of private entrepreneurs into the NPC and the CPPCC is a way for the CCP to co-opt this

\footnotetext{
${ }^{6}$ See Chen and Dickson (2010) for a detailed discussion on entrepreneurs' participation in these political bodies.
} 
increasingly important socioeconomic class. Entrepreneurs who engage in political affairs will divert attention from their own business, which may potentially hurt firm performance. However, an entrepreneur's decision to join one of these political bodies is more than likely at least partly based on the premise that he or she will gain access to a powerful political network. It is thus worthwhile to investigate the net economic consequence of political participation by entrepreneurs on their own firms.

\subsection{Hypotheses}

The literature on political connections shows that connected firms are able to exploit different rent-seeking opportunities. The final outcome of such behavior on firms depends on whether the effects of political ties are dominated by rent seeking or the grabbing hand of the government. Faccio (2006) documents a positive market reaction for new acquisitions of political connections while Fisman (2000) finds negative market effects for a decline in political connections. The value of political capital can be due to subsidies for the connected firms during crisis (Johnson and Mitton, 2003) or bailouts when the connected firms are in financial trouble (Faccio et al, 2006). The research samples in these previous studies are typically dominated by family firms. However, Fan et al. (2007) show that listed SOEs in China tend to be negatively affected by political connections, indicating that the presence of politically connected people in management and on the board can be detrimental to firm value. Since we are focusing on private entrepreneurs, we expect that political participation will 
improve firm performance if it can create political capital similar to that of political connections. We thus have the following initial hypothesis:

Hypothesis 1: Political participation by an entrepreneur will result in a positive effect on the performance of firms under his or her control.

It should be noted that we may also find a negative effect on firm performance from political participation by the controlling entrepreneurs. This is because the effort of the controlling entrepreneurs, who are typically taking up key management positions in their firms, will be diverted to public affairs. In this paper, we look at the relationship between political participation and firm performance effects by analyzing stock performance as well as operating performance.

While the effects of political connections on firm performance have been analyzed in earlier studies, less effort has gone into identifying and analyzing channels of preferential treatment. This is most likely due to data limitations. A more detailed analysis on such potential channels is provided in this paper as we address the following hypothesis:

Hypothesis 2: Political participation by an entrepreneur will result in a preferential treatment of firms under his or her control.

In this study, we identify and test several channels that can be used for preferential treatment. First, previous research has shown that political networks can improve firms' access to capital (e.g. Khawaja and Mian, 2006). Dinc (2005) finds that government-owned banks tend to increase their lending during election years, while Claessens et al. (2008) show how 
Brazilian firms are more likely to exhibit increased access to bank financing after elections if they make large contributions to election campaigns. In China, most capital is channeled through the banking system, which in turn is controlled by the state (Allen et al, 2005, 2008). This makes it likely that relationships obtained through political participation result in preferential access to debt financing. Second, Charumilind et al. (2006) find that firms with political connections have better access to long-term financing than regular firms. Similarly, Fan et al. (2008) find a significant decline in leverage and debt maturity ratios for firms connected to corrupted bureaucrats after corruption scandals involving the bureaucrats in question become public. We thus hypothesize that political participation results in preferential access to debt financing in general and long-term debt financing in particular.

Besides preferential access to debt financing, we identify three additional potential channels for preferential treatment. It is commonly argued that state-owned enterprises (SOEs) receive preferential treatment by the Chinese government compared to private firms. One way for privately controlled firms to receive similar preferential treatment may be by forging important relationships through political participation ( $\mathrm{Li}$ et al., 2004). Potential ways for the government to facilitate such preferential treatment could for example be through government subsidies or lower taxes. For instance, Girma et al. (2009) show that industry subsidies totaled well over US\$300 billion between 1995 and 2005 with about half of that amount going to state-owned enterprises. Moreover, there are a number of industries that are heavily regulated in China, including the energy, natural resources, and finance sectors. In addition to superior 
access to debt capital, we thus conjecture that political participation may have a significant effect on firm performance through more government subsidies, lower effective tax rates, and better access to regulated industries.

\section{Data and Sample Description}

We first identify all listed firms on the Shanghai and Shenzhen stock exchanges that are controlled by private individuals between 1993 and 2011. Panel A in Table 1 shows the total number of listed firms and the number of privately controlled firms for each year during the sample period. The number of firms controlled by private entrepreneurs was very modest during the $1990 \mathrm{~s}$, never reaching above $10 \%$ of the total number of listed firms. During the following decade, however, the ratio of privately controlled firms to the total number of listed firms increased fast. In 1993, the total number of listed firms was 183, of which private entrepreneurs controlled only six. In 2011, the total number of listed firms had increased to 2,342 , of which private entrepreneurs controlled 1,206 . This means that the ratio of firms controlled by private entrepreneurs to the total number of listed firms increased from a mere $3.3 \%$ to $51.5 \%$ over the sample period. This change mirrors the overall development in the Chinese economy in which privately controlled firms have become increasingly important.

The new term of membership in the NPC and CPPCC begins the year after the national congress of the CCP. Participants will typically be members over five-year periods and join the congress each year within their term. Thus, we identify the initial year that they participate in 
either the NPC or CPPCC and define that as the event year. We thus look at year 1993, 1998, 2003 and 2008 for participation by entrepreneurs (or one of their family members) who control a publicly listed company. In these four years, we find 86 entrepreneurs or their family members who participate in either the NPC or CPPCC. Of these 86 firms, 83 were controlled by entrepreneurs who began to participate in high-level politics during the congresses of 2003 and 2008. Only three began to participate in politics at the provincial or national level in 1998 and none did so in 1993. This indicates that not only were private entrepreneurs allowed to begin to participate in politics during the 2000s; they themselves clearly found it attractive to do so. In 1998,2003 , and $2008,5.66 \%, 15.49 \%$, and $8.68 \%$ of all listed entrepreneurial firms were controlled by an entrepreneur who began to participate in politics. We use all privately controlled firms without political participation in the same year as the control sample.

[Table 1 about here]

\section{Effects of Entrepreneurial Political Participation}

\subsection{Political Participation and Stock Performance}

To analyze the effects of political participation, we look at stock performance over 36 months after the controlling private entrepreneur begins to participate in politics. We measure stock performance as the buy-and-hold abnormal returns (BHARs) in a window of $[1,36]$ with 
the month in which the entrepreneur begins to participate in politics set as time zero. ${ }^{7} \mathrm{We}$ provide results for stock performance using both an equally-weighted all A-share index and a tradable-weighted all A-share index as benchmarks. For completeness, and similar to Daniel et al. (1997), we also measure stock performance as excess returns relative to portfolios that are matched based on size, book-to-market (B/M), and momentum factors. ${ }^{8}$ Panel $\mathrm{A}$ in Table 2 presents the mean and median of the different variables for the two sample groups. The BHARs based on an equally-weighted index portfolio is $16.9 \%$ for firms controlled by entrepreneurs who participate in politics and $-2.2 \%$ for firms controlled by other entrepreneurs. The difference is even larger when using the tradable value-weighted index, 55.4\% against a modest $12.4 \%$. The same pattern applies for the matching portfolios and the univariate tests show that the BHARs are significantly larger for firms controlled by entrepreneurs who participate in politics.

We estimate ordinary least squares (OLS) regressions with heteroskedasticity-robust standard errors clustered by industry and year (Petersen, 2009; Thompson, 2011), and with the

\footnotetext{
${ }^{7}$ We use BHARs rather than cumulative abnormal returns (CARs) because Barber and Lyon (1997) and Lyon et al. (1999) suggest that this approach yields well-specified test statistics for the long-run behavior of stock returns following corporate events.
${ }^{8}$ Fama and French $(1992,1993)$ and Carhart (1997) find that these factors are important determinants of the cross-section of stock returns.


four different BHARs as dependent variables. ${ }^{9}$ The main independent variable is political participation, a dummy variable, which equals one if the controlling entrepreneur begins to participate in politics and zero otherwise. We also control for the following factors in the model: family ownership, measured by the percentage ownership by the controlling family; state ownership, defined as the sum of state ownership among the ten largest shareholders; Tobin's $Q$, measured by the sum of total market value and total net liabilities over total assets; leverage, measured by total liabilities over total assets; size, defined as the natural logarithm of total assets.

Panel B in Table 2 reports the regression results. Even when taking all control variables into account, political participation has a significantly positive effect on long-run stock performance. The effect is significant at the $5 \%$ level for the BHARs based on the equallyweighted index and at the $1 \%$ level for the BHARs using other three benchmarks. Consistent with the univariate results in Panel A, we find that political participation by entrepreneurs results in an increase rather than decrease in long-run stock performance of firms under their control, implying that there is a significant value injected to the company originating from the political capital derived from political participation. The cost of political participation, if any, does not dominate.

[Table 2 about here]

${ }^{9}$ All results in this study control for both heteroskedasticity and possible dependence within clusters. 


\subsection{Political Participation and Operating Performance}

To further analyze the effects of political participation on operating performance, we compare changes in operating performance after the beginning of political participation. We focus on six different measures of operating performance. First, we look at growth in assets, sales, and earnings, which we calculate as the difference in the logarithm of the three-year average of each measure before and after the entrepreneur begins to participate in politics. Second, we define change in return on sales (ROS), return on assets (ROA), and return on equity (ROE) as the difference between the averages of each measure during three years after and three years before the entrepreneur begins to participate in politics. Before moving on to the regression analysis, we perform initial tests for differences in the mean and median of the two groups for all six operating performance measures. Panel A in Table 3 presents the descriptive statistics and the results of univariate tests. Both the mean and median of all six measures are significantly larger for firms that are controlled by private entrepreneurs who begin to participate in politics. For instance, growth in assets and sales are both more than twice as large for firms controlled by entrepreneurs who begin to participate in politics, and growth in earnings is $66.3 \%$ compared to a decline of $9.2 \%$ for other firms controlled by entrepreneurs. These initial results suggest that there is a significant positive effect on a firm's operating performance after its controlling entrepreneur becomes a member of the NPC or the CPPCC. 
To control for other variables that may influence operating performance, we again estimate OLS regressions using the six measures of operating performance as dependent variables. Panel B in Table 3 presents the results of the regressions with political participation as the main independent variable and family ownership, state ownership, Tobin's Q, leverage, size, and industry and year dummies as control variables. The regression results show that firms controlled by private entrepreneurs who begin to participate in politics experience an improved operating performance, regardless of whether the change in performance is measured by growth in assets, sales or earnings, or the change in ROS, ROA, or ROE, respectively. We can therefore conclude that political participation by the controlling private entrepreneur has a significant positive effect not only on stock performance, but also operating performance. These initial results suggest that the net of the economic consequences from political participation is positive. The benefit induced by political capital from political participation is at least as significant as that from political connections (e.g. Fisman, 2001; Faccio, 2006; and Ferguson and Voth, 2008). Having established that political participation is positively related to firm value and firm performance, we now focus on potential channels of preferential treatment for firms controlled by entrepreneurs who participate in politics.

[Table 3 about here] 


\section{Identifying Causes behind the Effects of Political Participation}

\subsection{Access to Debt Financing and Debt Maturity}

We begin our analysis of potential preferential treatment by looking at debt structure and debt maturity. Our hypothesis is that political participation results in better access to debt financing, something that most likely results in changes to debt structure and debt maturity. To shed light on the effects on debt structure, we follow the capital structure literature and focus on leverage (e.g. Harris and Raviv, 1991; Rajan and Zingales, 1995). We calculate leverage as total debt over total assets. For robustness, we also analyze total debt plus accounts payable over total assets. Using these two variables, we look at the change in the capital structure by calculating the difference of the post-event three-year average and the pre-event three-year average. To analyze effects on debt maturity, we follow Fan et al. (2008) and focus on the change in long-term debt over total debt and the long-term debt over total debt plus accounts payable. ${ }^{10}$

Panel A in Table 4 provides a description of the sample based on the debt-related variables. Initial univariate tests indicate that firms controlled by private entrepreneurs who begin to participate in politics experience a significant positive change in their debt ratio. Both

\footnotetext{
${ }^{10}$ If a firm has no long-term debt, we denote it as zero. If a firms' debt is zero both before and after political participation, the change in debt is also zero. For robustness, we also ran the regressions without these observations, after which the results remained qualitatively the same.
} 
change in total debt over total assets and the change in total debt plus accounts payable over total assets are significantly larger in the mean and median. After the controlling entrepreneurs begin to participate in high-level politics, their firms are thus able to increase their leverage more than other firms controlled by private entrepreneurs. For debt maturity, it is evident that political participation increases long-term debt as share of total debt, as well as long-term debt as share of total debt plus accounts payable.

Next, we run regressions to examine whether the financing policies of the firms in the research sample change after the controlling entrepreneur begins to participate in politics. In addition to the control used earlier, we also include two additional factors that can potentially affect debt maturity and capital structure: profitability, measured as earnings over total assets, and collateral, measured as net fixed assets over total assets. These are standard control variables in the debt finance and capital structure literature. Finally, we again include industry and year dummies. Panel B in Table 4 reports the regression results with each of the four debt measures as dependent variable. Change in total debt over total assets as well as change total debt plus accounts payable over total assets are influenced by political participation. The effect is positive and significant, indicating that firms controlled by entrepreneurs who begin to participate in politics are better able to increase their leverage compared to normal private firms. Looking instead at the changes in debt maturity, the effect is still positive and significant at the $1 \%$ level for both measures. These results indicate that firms controlled by private entrepreneurs who begin to participate in politics are better able to shift to long-term debt than 
normal private firms. The significance of political participation in each of the four regressions shows that the changes in leverage and debt maturity cannot be explained only by differences in other corporate fundamentals or industry and year effects. The findings in Table 4 thus demonstrate how debt financing behavior changes as private entrepreneurs begin to participate in politics.

[Table 4 about here]

\subsection{Tax Burden}

Johnson et al. (2000) show that firms in some developing and transition economies such as Russia and Ukraine face higher effective tax rates. This forces them to operate underground, which in turn impedes economic growth. China is absent in their study, but anecdotes about the high corporate tax burden in China abound in media and reports (e.g. Forbes, 2009; Market Watch, 2011; China Briefing, 2011; Caijing, 2013). Although the formal tax rate is generally regulated by the Ministry of Finance and State Administration of Taxation in China, its enforcement and all types of tax reduction/refund and extra informal taxes are, to some degree, at the discretion of bureaucrats at different levels (Wong, 1998; Cao, 2011). In a related study, Adhikari et al. (2006) find that firms that are politically connected in Malaysia pay a significantly lower effective tax rate than other firms. We propose that a similar effect may exist in China. That is, political participation by entrepreneurs can help reduce tax burden for firms under their control. 
To analyze the potential changes in tax payments after entrepreneurs begin to participate in politics, we focus on the effective tax rate (ETR). Following the related literature (e.g. Porcano, 1986; Gupta and Newberry, 1997), ETR1 is defined as the tax expense minus deferred tax expense divided by earnings before interest and tax (EBIT). For completeness, we also use two alternative ETR measures: ETR2 is defined as tax expenses over EBIT and ETR3 is defined as tax expenses over total profit (Wu et al., 2007). To analyze the effect of political participation, we then calculate the change in tax burden as the difference between the average annual ETR during three years after the event and the average annual ETR during three years before the event. Panel A in Table 5 reports the mean and median values of the change in the three different tax burden measures. The initial univariate tests for differences in the mean and median show that firms controlled by entrepreneurs who begin to participate in politics exhibit a significant decline in their tax burden. The change in ETR for firms controlled by entrepreneurs who begin to participate in politics is negative in both mean and median and for all three measures. The change for other firms controlled by private entrepreneurs during the same periods is much smaller with positive median values in all three cases and very small negative mean values in two measures of tax burden.

Panel B in Table 5 reports the results of the regressions with each of the three tax burden measures as dependent variables. Here, we include standard control variables from the literature on tax rates: capital intensity, defined as the net fixed assets over total assets, and inventory intensity, defined as inventory over total assets; and profitability, as defined in the 
previous section. The independent variable of interest is again political participation. The coefficient for political participation is negative and significant for all three tax burden measures. Even when controlling for various alternative factors that may influence the effective tax rate, our results show that political participation by the controlling private entrepreneur significantly eases the tax burden at the 5\% and $1 \%$ levels depending on the definition of tax burden. Chinese business owners are thus able to gain preferential treatment in the form of lower levels of tax burden after they begin to participate in politics.

[Table 5 about here]

\subsection{Government Subsidies}

Government subsidies are widely used in many developing countries, including China. Most studies (e.g. Lardy, 1998; Lin et al., 1998; Jefferson and Singh, 1999) tend to focus on the importance of subsidies for the state-owned sector, but differences in subsidies across segments of the private sector are potentially very important. Studies on rent seeking argue that entrepreneurs have strong incentives to collude with corrupt or self-served politicians in order to extract rents such as subsidies (Krueger, 1974; Shleifer and Vishny, 1994; Hellman et al., 2003; Morck et al., 2005). Different from typical productive activities, obtaining subsidies may turn out to be an easy task that only consumes a negligible amount of energy for entrepreneurs who have developed strong relationships with government officials or bureaucrats. 
Here, we focus on how Chinese firms controlled by private entrepreneurs receive different amounts of subsidies. We use three alternative measures for government subsidies: government subsidyl is defined as total government subsidies over EBIT; government subsidy 2 is defined as total government subsidies over total earnings; and government subsidy 3 is defined as total government subsidies over total sales. Our goal is again to analyze the change when entrepreneurs begin to participate in politics. We therefore define the dependent variable as the change in subsidies, which we calculate as the difference between the average annual government subsidies during three years after and the average annual government subsidies during three years before the entrepreneurs begin to participate in politics. Summary statistics of the three measures of government subsidies are presented in Panel A in Table 6. The change in government subsidies for firms controlled by entrepreneurs who begin to participate in politics is positive and significantly different for regular private firms in both the mean and median. In fact, both the mean and median are negative for regular private firms, indicating that changes in government subsidies are significantly skewed after the NPC and CPPCC during which new members are elected.

Panel B in Table 6 present the results when we control for a number of potential factors that may influence government subsidies. The independent variable political participation is significantly positive at the $5 \%$ and $1 \%$ levels, respectively. These results corroborate the initial findings in Panel A. We can thus conclude that political participation by private entrepreneurs brings with it substantial preferential treatment in the form of more government 
subsidies. This is an important benefit, not the least in China, where the general level of government subsidies is high.

[Table 6 about here]

\subsection{Access to Regulated Industries through $M \& A$ Deals}

Governments in transition economies often intervene by imposing comprehensive regulations that obstruct the development of a sound private sector (De Soto, 1989; Hellman and Kaufmann, 2003; Li et al., 2006; World Bank, 2004, 2012). Such regulations not only impede competition and inhibit progress at the macro level, but also deprive entrepreneurs of potential business opportunities (e.g. Stigler, 1971; Christiansen and Haveman, 1982; Guasch and Hahn, 1999). In China, heavily regulated industries such as finance and natural resource mining still provide for lucrative businesses for SOEs three decades after the beginning of the economic reforms. We therefore ask a perhaps bold but fundamental and important question: Can entrepreneurial political participation help their firms enter regulated industries? In particular, can such firms gain preferential access through beneficial mergers or acquisitions (M\&As) deals?

To analyze this potential way into regulated industries for privately controlled firms, we first identify M\&A deals by firms controlled by private entrepreneurs, and then perform a regression analysis that focuses on access to regulated industries in China. Panel A in Table 7 presents descriptive statistics focusing on regulated industry entry through M\&A deals during 
three years following the NPC and CPPCC at which new members were elected. Panel A reports the regulated industry and firm characteristics. We read each public M\&A announcement to identify the target firm's main industry. The variable regulated industry is equal 1 if the target firm is active in one of China's regulated industries such as finance, media, aerospace, natural resources mining, etc., and 0 otherwise. For firms controlled by entrepreneurs who begin to participate in politics, $24.4 \%$ of the deals took place in regulated industries, with a corresponding $6.2 \%$ for firms controlled by other entrepreneurs. This mirrors the fact that it is difficult for privately controlled firms, especially those not controlled by private entrepreneurs who participate in politics, to get access to certain sectors of the Chinese economy.

To analyze the influence that political participation may have on gaining access to regulated industries, we perform a logistic regression with the dummy variable regulated industry as the dependent variable. Besides political participation, we include the same standard control variables that we have used earlier in this study as well as industry and year dummies. Panel B in Table 7 reports the regression results. The coefficient for regulated industry is significant and positive at the $1 \%$ level. We can therefore conclude that a firm which is controlled by a private entrepreneur who begins to participate in politics is more likely to carry out an M\&A transaction in a regulated industry. This means that political participation by private entrepreneurs in China can be used to gain preferential treatment in the 
form of superior access to industries that are heavily regulated and often closed to the private sector.

[Table 7 about here]

\section{Robustness Checks}

\subsection{Controlling for Recognition Effects Using Lists over Wealthy Individuals}

The results in the previous sections show that when entrepreneurs begin to participate in high-level politics, there is a significant and positive effect on stock and operating performance. We have traced these effects to a number of different channels, including improved access to debt financing, lower taxes, more government subsidies, and better access to regulated industries. While these findings indicate that political participation facilitates rent seeking, it can be argued that the effects on firm performance may simply be due to an increase in the recognition of the controlling shareholder's entrepreneurial abilities. Such increased public recognition could then be used by the entrepreneur to, for example, gain better access to corporate financing. To control for this alternative explanation, we need an instrument that controls for public recognition of entrepreneurial abilities. Our focus on large and publicly listed firms that are controlled by entrepreneurs means that lists of Chinese affluent individuals constitute a suitable instrument. We combine the three most commonly used lists for wealthy individuals in mainland China: Hurun, New Fortune, and the Forbes List. We then create a 
dummy variable which is equal to 1 if the controlling entrepreneur is listed on any of the three lists and 0 otherwise.

Finally, we run the regressions on stock and operating performance one more time. Table 8 shows the regression results with stock performance as the dependent variable. The large and positive effect of political participation is still significant at the $1 \%$ level, indicating that the performance effects are not driven by public recognition. In fact, being on one of the three lists actually has a significant negative effect, regardless of which measure we use for stock performance. This finding suggests that it is not public recognition that is driving the change in stock performance when the controlling entrepreneur begins to participate in politics.

\section{[Table 8 about here]}

Table 9 presents the results with the different measures of operating performance as dependent variables. Being on one of the lists is insignificant in all cases except for when we use the change in return on sales as the dependent variable, for which the effect of public recognition on operating performance is negative. Turning instead to the coefficient for political participation, it is positive and significant at the $1 \%$ level for all six measures of 
operating performance. These results support the findings in Table 8, and suggest that it is not public recognition that is driving the performance effects. ${ }^{11}$

[Table 9 about here]

\subsection{Controlling for Recognition Effects using Local Institutions}

Using the different lists for affluent individuals as proxy for public recognition of entrepreneurial abilities can relieve concern on alternative explanation, but it also introduces a new issue. That is, being on the list cannot precisely proxy for the public recognition accompanying political participation, even if it indeed controls for the general public recognition effect. In other words, we explain our results mainly using the potential rentseeking mechanism, largely ignoring the celebrity effect. To further strengthen our argument, we consider the mechanisms through which rent seeking and public recognition work. Although increased rent seeking and public recognition have the same effect on privately controlled firms as a result of political participation, they work through different mechanisms. The public recognition effect, on one hand, is similar to a typical reputation effect and mainly works through market mechanisms. However, the rent-seeking mechanism is more effective in more corrupt environments. We therefore design a new test to shed further light on whether the

\footnotetext{
${ }^{11}$ We also find that the effect of political participation on debt financing, tax burden, government subsidies and better access to heavily regulated industries through M\&A deals remain significant after controlling for public recognition using the lists for affluent individuals again. These results are not reported to save space.
} 
performance effects are due to rent seeking or public recognition. To do this, we first divide the sample into two groups based on local institutions in the province in which a firm's headquarter is located. We argue that if the performance effect is larger in regions with more opportunities for rent seeking, it will indicate that the difference is mainly due to rent seeking rather than public recognition, and vice versa. We thus conduct tests similar to those in previous sections, adding the proxies for rent-seeking opportunities.

We first use the National Economic Research Institute (NERI) Index of Marketization ${ }^{12}$ for China's provinces to proxy for local institutions because more developed markets can improve local institutions in a transition economy such as China (Wang et al, 2007). We thus divide the sample into two groups based on the level of marketization. Second, we use protection of property rights as a local institution proxy. We obtain data on property rights from a World Bank survey that focuses on China's larger cities (World Bank, 2006). Here, the firms are divided into two groups depending on whether or not their headquarters are located in places with relatively lower levels of property protection. Third, we follow earlier studies such

\footnotetext{
${ }^{12}$ The NERI index measures the progress of each province (relative to other provinces) in its transition into a market economy. The index is composed of 23 indicators of institutional arrangements and policies within five different areas: size of the regional government; economic structure (growth of the non-state sector and the reform of state-controlled firms); inter-regional trade barriers; development of factor markets; and legal framework. For more details on the index, see Wang et al. (2007).
} 
as Faccio (2006) and use GDP per capita as a proxy for local institutions. To sum up, low levels of marketization, weak property rights and lower real GDP per capita should be conducive for rent seeking.

Table 10 reports the results of political participation and institution on firm performance. For brevity, we just use three-year BHARs based on Size, B/M and momentum matching portfolios in Columns 1, 2, and 3, and the change in return on sales (ROS) in Columns 2, 4, and 6 to discuss the effects on stock performance and operating performance when private entrepreneurs begin to participate in politics. We alternatively measure institutions using the NERI marketization index in Columns 1 and 2, property rights in Columns 3 and 4, and real GDP per capita in Columns 5 and 6. Here, the dummy variable for institutions is equal to 1 when a firm's headquarter is located in a region with a lower institutional quality than that of the sample median, and zero otherwise. This means that the institution dummies proxy for higher rent-seeking opportunities.

We first look at the stock performance results presented in Columns 1, 2, and 3 in Table 10. The coefficient for political participation, which now captures the effect of political participation in regions with less rent-seeking opportunities, remains positive and statistically significant in all three models, but the magnitude is reduced significantly. The coefficients for institutions are statistically insignificant, but the coefficients for the interaction terms between institutions and political participation are all significantly positive at the $1 \%$ level, indicating that political participation for firms in regions with richer rent-seeking opportunities are more 
valuable. Therefore, we can conclude that it is the political rent-seeking argument rather than the public recognition story that is driving our results. If the latter were to act as the main driver behind the performance effect, political participation should have a larger impact in regions characterized by stronger institutions, and thus the coefficients for the interaction term would become negative. Our findings are just the opposite. The results for operating performance in Columns 2, 4, and 6 tell the same story. Based on these findings, we can further eliminate the possibility that it is public recognition that is the main driver behind our earlier results.

[Table 10 about here]

\section{Conclusion}

This paper examines the effects of Chinese private entrepreneurs entering into politics. The event that we focus on is thus defined as the time that the controlling private entrepreneur begins to participate in politics by becoming a member in one of two important political bodies, the NPC or the CPPCC. Consistent with the literature on rent seeking and political connections, we find that political participation has a positive effect on firm value and operating performance. This indicates that private entrepreneurs are able to utilize their improved access to leading politicians for rent seeking.

We then examine several potentially important channels for rent seeking. First, we find that firms controlled by private entrepreneurs who begin to participate in politics are able to 
increase their leverage more than other privately controlled firms after the event. We also find that political participation has a positive effect on changes in long-term debt relative to total debt. These results indicate that political participation results in advantages in the form of better access to debt financing, which in turn affects the capital structure. Our findings on the effect of political participation on debt financing thus support recent research findings suggesting that financing patterns are affected not only by factors at the firm or industry level, but also at the country level (e.g. Rajan and Zingales, 1995; Demigurc-Kunt and Maksimovic, 1996, 1998, 1999; Booth et al., 2001).

Second, we look at several alternative measures of tax burden. Our findings show that political participation results in a negative effect on change in effective tax rates (ETRs). This suggests that private entrepreneurs in China are able to exploit the networks they build up through political participation to lower their firms' tax burden. Third, we find that political participation is positively associated with government subsidies change. Fourth, we analyze how firms' corporate deals are affected by political participation. We find that political participation significantly increases the likelihood of corporate deals in China's regulated industries. This means that private entrepreneurs have better access to regulated industries after they begin to participate in politics. We also control for public recognition and find that political participation still has a significant impact on firm performance, indicating that it is increased opportunities for rent seeking, rather than effects of an increase in recognition of an entrepreneur's abilities, that are driving the performance effects. Finally, we use local 
institutions to further disentangle the political rent seeking and public recognition arguments, finding again that political rent seeking is the main driver behind our findings

Our paper makes several important contributions to the literature on political participation by private entrepreneurs, political connections and rent seeking. First, we document how China's private entrepreneurs can choose to become members of major political bodies and thereby improve their firms' performance through rent seeking. Second, and more importantly, we identify several important rent seeking channels which private entrepreneurs are able to exploit through political participation, including better access to debt financing, reductions in tax burden, more government subsidies, and better access to heavily regulated industries in China. Our results should be useful when trying to understand problems in other emerging economies with similar institutional features. 


\section{References}

Adhikari, A., Derashid, C., Zhang, H., 2006. Public policy, political connections, and effective tax rates: Longitudinal evidence from Malaysia. Journal of Accounting and Public Policy 25, 574-595.

Allen , F , Qian, J., Qian, M.J., 2005. Law, finance, and economic growth in China. Journal of Financial Economics 77, 57-116.

Allen, F., Qian, J., Qian, M.J., 2008. China's financial system: Past, present, and future. In Brandt, L., Rawski, T.G., China's great economic transformation. Cambridge: Cambridge University Press.

Barber, B.M., Lyon, J.D., 1997. Detecting long-run abnormal stock returns: the empirical power and specification of test statistics. Journal of Financial Economics 43, 341-372.

Benmelech, E., Moskowitz, T., 2010. The political economy of financial regulation: Evidence from U.S. state usury laws in the 19th Century. Journal of Finance 65, 1029-1073.

Booth, L., Aivazian, V., Demirguc-Kunt, A., Maksimovic, V., 2001. Capital structures in developing countries. Journal of Finance 56, 87-130.

Caijing, 2013. Chinese corporate tax burden higher than OECD average: Report. 25 July 2013.

Cao, F., 2011. Corporate income tax law and practice in the People's Republic of China. Oxford University Press.

Carhart, M., 1997. On persistence in mutual fund performance. Journal of Finance 52, 57-82.

Charumilind, C., Kali, R., Wiwattanakantang, Y., 2006. Connected lending: Thailand before the financial crisis. Journal of Business 79, 181-218.

Chen, G.M., Firth, M., Xu, L., 2009. Does the type of ownership control matter? Evidence from China's listed companies. Journal of Banking and Finance 33, 171-181.

Chen, J., Dickson, B.J., 2010. Allies of the state: China's private entrepreneurs and democratic change. Cambridge, MA: Harvard University Press. 
Chen, X. Lee, C.W.J. and Li, J., 2008, Government Assisted Earnings Management in China, Journal of Accounting and Public Policy 27, pp 262-274.

China Briefing, 2011. China total tax burden second highest in world. 26 September 2011.

Christainsen, G.B. , Haveman, R.T.H., 1982. Government regulations and their impact on the economy. Annals of the American Academy of Political and Social Science, 112-122.

Claessens, S., Feijen, E., Laeven, L., 2008. Political connections and preferential access to finance: The role of campaign contributions. Journal of Financial Economics 88, 554-580.

Cooper, M.J., Gulen, H., Ovtchinnikov, A.V., 2010. Corporate political contributions and stock returns. Journal of Finance 65, 687-724.

Daniel, K., Grinblatt, M., Titman, S., Wermers, R., 1997. Measuring mutual fund performance with characteristic-based benchmarks. Journal of Finance 52, 1035-1058.

Demirguc-Kunt, A., Maksimovic, V., 1996. Stock market development and firm financing choices. World Bank Economic Review 10, 341-369.

Demirguc-Kunt, A., Maksimovic, V., 1998. Law, finance and firm growth. Journal of Finance $53,2107-2137$.

Demirguc-Kunt, A., Maksimovic, V., 1999. Institutions, financial markets, and firm debt maturity. Journal of Financial Economics 54, 295-336.

De Soto, H., 1989. The other path: The invisible revolution in the Third World. New York: Harper and Row.

Dinc, I.S., 2005. Politicians and banks: Political influence on government-owned banks in emerging markets. Journal of Financial Economics 77, 453-479.

Dickson, B.J., 2003. Red capitalists in China: The party, private entrepreneurs, and prospects for political change. New York: Cambridge University Press.

Dickson, B.J., 2008. Wealth into power: The communist party's embrace of China's private sector. New York: Cambridge University Press 
Dinc, I.S., 2005. Politicians and banks: Political influence on government-owned banks in emerging markets. Journal of Financial Economics 77, 453-479.

Dougherty, S., Herd, R., He, P., 2007. Has a private sector emerged in China's industry? Evidence from a quarter of a million Chinese firms. China Economic Review 18, 309-334.

Faccio, M., 2006. Politically connected firms. American Economic Review 96, 369-386.

Faccio, M., Masulis, R.W., McConnell, J.J., 2006. Political connections and corporate bailouts. Journal of Finance 61, 2597-2635.

Fama, E.F., French, K.R., 1992. The cross-section of expected stock returns. Journal of Finance 47, 427-465.

Fama, E.F., French, K.R., 1993. Common risk factors in returns on stocks and Bonds. Journal of Financial Economics 33, 3-56.

Fan, J.P.H., Rui, O.M., Zhao, M., 2008. Public governance and corporate finance: evidence from corruption cases. Journal of Comparative Economics 36, 343-364.

Fan, J.P.H., Wong, T.J., Zhang, T., 2007. Politically connected CEOs, corporate governance, and post-IPO performance of China's newly partially privatized firms. Journal of Financial Economics 84, 330-357.

Feng, X., Johansson, A.C., Zhang, T., 2011. Political participation and entrepreneurial initial public offerings in China. China Economic Research Center Working Paper Series No. 17, Stockholm School of Economics.

Ferguson, T., Voth, H.-J., 2008. Betting on Hitler - The value of political connections in Nazi Germany. Quarterly Journal of Economics 123, 101-137.

Fisman, R., 2001. Estimating the value of political connections. American Economic Review 91, 1095-1102.

Forbes, 2009. Tax misery \& reform index. 3 April 2009.

Girma, S., Gong, Y., Görg, H., Yu, Z., 2009. Can Production Subsidies Explain China's Export Performance? Evidence from Firm-Level Data. Scandinavian Journal of Economics $111,863-891$. 
Goldman, E., Rocholl, J., So, J., 2009. Do politically connected boards affect firm value? Review of Financial Studies 22, 2331-2360.

Guasch, J.L., Hahn, R.W., 1999. The costs and benefits of regulation: Implications for developing countries. The World Bank Research Observer 14, 137-158.

Gupta, S., Newberry, K., 1997. Determinants of the variability in corporate effective tax rate: Evidence from longitudinal data. Journal of Accounting and Public Policy 16, 1-39.

Harris, M., Raviv, A., 1991. The theory of capital structure. Journal of Finance 46, 297-355.

Hellman, J., Jones, G., Kaufmann , D., 2003. Seize the state, seize the day: State capture, corruption and influence in Transition. Journal of Comparative Economics 31, 751-773.

Jayachandran, S., 2006. The Jeffords effect. Journal of Law and Economics 49, 397-425.

Jefferson, G.H., Singh, I., 1999. Enterprise reform in China: Ownership, transition, and performance. New York: Oxford University Press.

Johnson, S., Kaufmann, D., McMillan, J., Woodruff, C., 2000. Why do firms hide? Bribes and unofficial activity after communism. Journal of Public Economics 76, 495-520.

Johnson, S., Mitton, T., 2003. Cronyism and Capital Controls: Evidence from Malaysia. Journal of Financial Economics 67, 351-382.

Khwaja, A., Mian, A., 2005. Do lenders favor politically connected firms? Rent provision in an emerging financial market. Quarterly Journal of Economics 120, 1371-1411.

Knight, B., 2006. Are policy platforms capitalized into equity prices? Evidence from the Bush/Gore 2000 presidential election. Journal of Public Economics 90, 751-773.

Kroszner, R. S., Stratmann, T.E., 1998. Interest-group competition and the organization of Congress: Theory and evidence from financial services' political action committees. American Economic Review 88, 1163-1187.

Krueger, A., 1974. The political economy of the rent-seeking society. American Economic Review 64, 291-303. 
La Porta, R., Lopez-de-Silanes, F., Shleifer, A., 1999. Corporate ownership around the world. Journal of Finance 54, 471-518.

La Porta, R., Lopez-de-Silanes, F., Shleifer, A., Vishny, R., 2002. Investor protection and corporate valuation. Journal of Finance 57, 1147-1170.

Lardy, N.R., 1998, China's unfinished economic revolution. Washington, D.C.: Brookings Institution Press.

Li, H., Meng, L., and Zhang, J., 2006. Why do entrepreneurs enter politics? Evidence from China. Economic Inquiry, 44, 559-578.

Lin, J. Y., Cai, F. Li, Z. 1998. Competition, Policy Burdens, and State-Owned Enterprise Reform", American Economic Review 88, 422-427.

Lyon, J., Barber, B., Tsai, C., 1999, Improved methods for tests of long-run abnormal stock returns, Journal of Finance 54, 165-201.

Market Watch, 2012. The mystery of China's tax burden: Tax rates have soared, but policies try to hide the burden. 24 April 2012.

Morck , R., Wolfenzon, D., Yueng, B., 2005. Corporate governance, economic entrenchment , and growth. Journal of Economic Literature 43, 655-720.

Petersen, M.A., 2009. Estimating standard errors in finance panel data sets: Comparing approaches. Review of Financial Studies 22, 435-480.

Porcano, T.M., 1986. Corporate tax rates: Progressive, proportional, or regressive. Journal of the American Taxation Association 7, 17-31.

Rajan, R., Zingales, L., 1995. What do we know about capital structure? Some evidence from international data. Journal of Finance 50, 1421-1460.

Rajan, R., Zingales, L., 2003. The Great Reversals: The politics of financial development in the 20th century. Journal of Financial Economics 69, 5-50.

Roberts, B., 1990. A dead senator tells no lies: Seniority and the distribution of Federal benefits. American Journal of Political Science 34, 31-58. 
Shambaugh, D., 2009. China's Communist Party: Atrophy and adaptation. Berkeley, CA: The University of California Press.

Shleifer, A. Vishny, R., 1994. Politicians and firms. Quarterly Journal of Economics 109. 995-1025.

Stigler, G.J., 1971. The theory of economic regulation. Bell Journal of Economics and Management Science 2, 3-21.

Thompson, S., 2011. Simple formulas for standard errors that cluster by both firm and time. Journal of Financial Economics 99, 1-10.

Tsai, K.S., 2006. Adaptive informal institutions and endogenous change in China. World Politics 59, 116-141.

Tsai, K.S., 2007. Capitalism without democracy: The private sector in contemporary China. Ithaca, NY: Cornell University Press.

Tsui, A.S., Bian, Y., Cheng, L., 2006, China's domestic private firms: Multidisciplinary perspectives on management and performance. M.E.Sharpe.

Wang, X., Fan, G., Zhu, H., 2007. Marketisation in China: progress and contribution to growth, in: Garnaut, R., Song, L. (Eds) China linking markets for growth. Canberra: ANU E Press and Asia Pacific Press.

Wong, C., 1998. Fiscal Dualism in China: Gradualist reform and the Ggowth of off-budget finance. In (ed) Brean, D., Taxation in modern China. New York: Routledge, 187-208.

World Bank, 2003. Doing business in 2004: Understanding regulation. Washington, D.C.: World Bank.

World Bank, 2012. China 2030: Building a modern, harmonious, and creative high-income society. Washington, D.C.: World Bank.

Wright, T., 2010. Accepting authoritarianism: State-society relations in China's reform era. Stanford, CA: Stanford University Press. 
Wu, L., Wang, Y., Lin, B.,-X., Li, C., Chen, S., 2007. Local tax rebates, corporate tax burdens, and firm migration: Evidence from China. Journal of Accounting and Public Policy 26, 555583. 


\section{Table 1 Sample}

\section{Panel A: Distribution of Listed Privately Controlled Firms}

This panel presents the distribution of listed privately controlled firms by year during 1993-2011. Privately controlled firms are defined as firms controlled by a private entrepreneur or his or her family.

\begin{tabular}{cccc}
\hline \multirow{2}{*}{ Year } & $\begin{array}{c}\text { Number of all } \\
\text { listed firms }\end{array}$ & \multicolumn{2}{c}{ Privately Controlled Firms } \\
\cline { 3 - 4 } & 183 & 6 & $\begin{array}{c}\text { As percentage of all } \\
\text { listed firms (\%) }\end{array}$ \\
\hline 1993 & 291 & 17 & 3.3 \\
1994 & 323 & 19 & 5.8 \\
1995 & 530 & 28 & 5.9 \\
1996 & 745 & 42 & 5.3 \\
1997 & 851 & 53 & 5.6 \\
1998 & 949 & 71 & 6.2 \\
1999 & 1088 & 96 & 7.5 \\
2000 & 1160 & 119 & 8.8 \\
2001 & 1224 & 152 & 10.3 \\
2002 & 1287 & 213 & 12.4 \\
2003 & 1377 & 291 & 16.6 \\
2004 & 1381 & 324 & 21.1 \\
2005 & 1434 & 404 & 23.5 \\
2006 & 1550 & 519 & 28.2 \\
2007 & 1625 & 576 & 33.5 \\
2008 & 1718 & 656 & 35.4 \\
2009 & 2063 & 949 & 38.2 \\
2010 & 2342 & 1206 & 46.0 \\
2011 & & & 51.5 \\
\hline
\end{tabular}


Table 1 Sample (Continued)

Panel B: Distribution of Firms Controlled by Entrepreneurs Who Participate in

\section{Politics}

This panel presents the distribution of firms that are controlled by private entrepreneurs who begins to participate in politics, defined as the entrepreneur (or one of his or her family members) becomes a member of the National People's Congress (NPC) or the Chinese People's Political Consultative Conference (CPPCC) at the national or provincial level.

\begin{tabular}{cccc}
\hline & \multirow{2}{*}{$\begin{array}{c}\text { Number of entrepreneurial } \\
\text { Yirms }\end{array}$} & $\begin{array}{c}\text { Firms controlled by entrepreneurs who begin to } \\
\text { participate in politics }\end{array}$ \\
\cline { 3 - 4 } & & Numbers & $\begin{array}{c}\text { As percentage of all entrepreneurial } \\
\text { firms (\%) }\end{array}$ \\
\hline 1993 & 6 & 0 & 0.00 \\
1998 & 53 & 3 & 5.66 \\
2003 & 213 & 33 & 15.49 \\
2008 & 576 & 50 & 8.68 \\
Total & 5471 & 86 & 1.57 \\
\hline
\end{tabular}


Table 2 Political Participation and Stock Performance

\section{Panel A: Descriptive Statistics and Univariate Tests}

This table presents descriptive statistics and univariate tests for stock performance in a window of $[1,36]$ with the month in which the entrepreneur begins to participate in politics set as time zero. The political participation sample is composed of private firms controlled by private entrepreneurs who begin to participate in politics. The no political participation sample is composed of private firms controlled by private entrepreneurs who do not participate in politics in the same year. The stock performance measures are calculated as buy-and-hold abnormal returns (BHARs), where the benchmarks are alternatively measured as equally weighted all A stock shares index, tradable value weighted all A stock shares index, Size and B/M matching Portfolios, and Size, B/M and momentum matching Portfolios. The other variables are: political participation, which equals one for the firm that the entrepreneur begins to participate in politics and zero otherwise; family ownership, measured as the percentage ownership by the controlling family; state ownership, measured as the sum of state ownership among the top 10 shareholders; Tobin's Q, measured as the sum of total market value and total net liabilities divided by total assets; leverage, measured as the ratio of total liabilities over total assets; size, measured as the natural logarithm of total assets. All variables are winsorized at the top and bottom $1 \%$. $* * *, * *$ and $*$ denote significance for the difference between the political participation sample and no political participation sample at $1 \%, 5 \%$, and $10 \%$ respectively.

\begin{tabular}{|c|c|c|c|c|c|c|c|c|}
\hline & \multicolumn{4}{|c|}{ Political Participation Sample } & \multicolumn{4}{|c|}{$\begin{array}{c}\text { No Political Participation } \\
\text { Sample }\end{array}$} \\
\hline & $\mathrm{N}$ & Mean & Median & Std. Dev & $\mathrm{N}$ & Mean & Median & Std. Dev \\
\hline $\begin{array}{l}\text { Return in excess of equally weighted all A } \\
\text { Stock Shares index }\end{array}$ & 86 & $0.169 * * *$ & $-0.062 * * *$ & 0.844 & 612 & -0.022 & -0.246 & 1.207 \\
\hline $\begin{array}{l}\text { Return in excess of tradable value weighted } \\
\text { all A Stock Shares index }\end{array}$ & 86 & $0.554 * * *$ & $0.273 * * *$ & 0.962 & 612 & 0.124 & 0.116 & 1.298 \\
\hline $\begin{array}{l}\text { Return in excess of Size and B/M matching } \\
\text { Portfolios }\end{array}$ & 86 & $0.338 * * *$ & $0.274 * *$ & 0.738 & 612 & 0.102 & 0.093 & 0.741 \\
\hline $\begin{array}{l}\text { Return in excess of Size, } \mathrm{B} / \mathrm{M} \text { and } \\
\text { momentum matching Portfolios }\end{array}$ & 86 & $0.433 * * *$ & $0.313 * *$ & 0.931 & 612 & 0.114 & 0.121 & 0.902 \\
\hline Family Ownership & 86 & 0.318 & 0.293 & 0.149 & 612 & 0.321 & 0.289 & 0.137 \\
\hline State Ownership & 86 & $0.024 * *$ & 0.000 & 0.068 & 612 & 0.071 & 0.000 & 0.153 \\
\hline Tobin's Q & 86 & 1.928 & 2.051 & 1.047 & 612 & 2.591 & 1.889 & 5.335 \\
\hline Leverage & 86 & 0.450 & 0.450 & 0.173 & 612 & 0.750 & 0.500 & 4.013 \\
\hline Size & 86 & 21.048 & $21.054 * *$ & 0.870 & 612 & 20.630 & 20.573 & 0.986 \\
\hline
\end{tabular}




\section{Table 2 Political Participation and Stock Performance (Continued)}

\section{Panel B: Multivariate analysis}

This table presents the OLS regression results of the effect of political participation on stock performance. The dependent variables are measured as the buy-and-hold abnormal returns (BHARs) in a window of [1, 36] with the month in which the entrepreneur begins to participate in politics set as time zero. The benchmarks are: the return in excess of equally weighted all A stock shares index; the return in excess of tradable value weighted all A stock shares index; the return in excess of Size and B/M matching Portfolios; and the return in excess of Size, B/M and momentum matching portfolios in models. The independent variables include political participation, which equals one for the firm that the entrepreneur begins to participate in politics and zero otherwise; family ownership, measured as the percentage ownership by the controlling family; state ownership, measured as the sum of state ownership among the top 10 shareholders; Tobin's Q, measured as the sum of total market value and total net liabilities divided by total assets; leverage, measured as the ratio of total liabilities over total assets; size, measured as the natural logarithm of total assets. Industry and year dummies are included but not reported. All continuous variables are winsorized at the top and bottom 1\%. T-statistics are given in parentheses and computed using heteroskedasticity-robust standard errors clustered by industry and year (Petersen, 2009; Thompson, 2011). $* * *, * *$, and $*$ denote significance at the $1 \%, 5 \%$, and $10 \%$ level, respectively.

\begin{tabular}{|c|c|c|c|c|}
\hline & $\begin{array}{c}(1) \\
\text { Return in } \\
\text { excess of } \\
\text { equally } \\
\text { weighted all A } \\
\text { Stock Shares } \\
\text { index }\end{array}$ & $\begin{array}{c}(2) \\
\text { Return in } \\
\text { excess of } \\
\text { tradable value } \\
\text { weighted all A } \\
\text { Stock Shares } \\
\text { index }\end{array}$ & $\begin{array}{c}(3) \\
\text { Return in } \\
\text { excess of Size } \\
\text { and B/M } \\
\text { matching } \\
\text { Portfolios }\end{array}$ & $\begin{array}{c}\text { (4) } \\
\text { Return in } \\
\text { excess of Size, } \\
\text { B/M and } \\
\text { momentum } \\
\text { matching } \\
\text { Portfolios }\end{array}$ \\
\hline Political & $0.171 * *$ & $0.241 * * *$ & $0.221 * * *$ & $0.306 * * *$ \\
\hline Participation & $(2.13)$ & $(3.78)$ & (3.53) & (4.09) \\
\hline $\begin{array}{l}\text { Family } \\
\text { Ownership }\end{array}$ & $\begin{array}{c}1.096^{* *} \\
(2.31)\end{array}$ & $\begin{array}{c}1.112 * * \\
(2.36)\end{array}$ & $\begin{array}{c}1.197 * * * \\
(6.41)\end{array}$ & $\begin{array}{c}1.219 * * * \\
(6.02)\end{array}$ \\
\hline $\begin{array}{l}\text { State } \\
\text { Ownership }\end{array}$ & $\begin{array}{l}-0.370 \\
(-1.00)\end{array}$ & $\begin{array}{l}-0.372 \\
(-1.01)\end{array}$ & $\begin{array}{l}-0.270 \\
(-1.42)\end{array}$ & $\begin{array}{l}-0.143 \\
(-0.97)\end{array}$ \\
\hline Tobin's Q & $\begin{array}{l}0.050 \\
(0.86)\end{array}$ & $\begin{array}{l}0.040 \\
(0.68)\end{array}$ & $\begin{array}{c}0.024 \\
(1.08)\end{array}$ & $\begin{array}{c}0.032 \\
(0.94)\end{array}$ \\
\hline Leverage & $\begin{array}{c}-0.305^{*} \\
(-1.70)\end{array}$ & $\begin{array}{c}-0.309^{*} \\
(-1.72)\end{array}$ & $\begin{array}{c}-0.151 * * \\
(-2.01)\end{array}$ & $\begin{array}{c}-0.253 \\
(-1.35)\end{array}$ \\
\hline Size & $\begin{array}{l}-0.045 \\
(-0.63)\end{array}$ & $\begin{array}{l}-0.044 \\
(-0.62)\end{array}$ & $\begin{array}{l}-0.062 \\
(-0.43)\end{array}$ & $\begin{array}{l}-0.024 \\
(-0.31)\end{array}$ \\
\hline Intercept & $\begin{array}{l}-1.010 \\
(-0.65)\end{array}$ & $\begin{array}{l}-0.301 \\
(-0.19)\end{array}$ & $\begin{array}{l}0.916 \\
(0.90)\end{array}$ & $\begin{array}{c}0.892 \\
(0.93)\end{array}$ \\
\hline $\begin{array}{l}\text { Industry/Year } \\
\text { Observations } \\
\text { Adjusted } R^{2}\end{array}$ & $\begin{array}{c}\text { Yes } \\
698 \\
0.221 \\
\end{array}$ & $\begin{array}{c}\text { Yes } \\
698 \\
0.216\end{array}$ & $\begin{array}{c}\text { Yes } \\
698 \\
0.227\end{array}$ & $\begin{array}{c}\text { Yes } \\
698 \\
0.221 \\
\end{array}$ \\
\hline
\end{tabular}




\section{Table 3 Political Participation and Operating Performance}

\section{Panel A: Univariate Test}

This table presents the descriptive statistics for the political participation sample and the no political participation sample as well as univariate tests for differences in means and medians. The political participation sample is composed of private firms controlled by private entrepreneurs who begin to participate in politics. The no political participation sample is composed of private firms controlled by private entrepreneurs who do not participate in politics in the same year. The growth in assets (sales, earnings, or operating earnings) are the growth rates of assets (sales, earnings, or operating earnings), calculated as the difference between the average annual assets (sales, earnings or operating earnings) during the three years before and the three years after the controlling entrepreneur begins to participate in politics. Similarly, ROS (ROA or ROE) is the difference between the average annual ROS (ROA or ROE) during the three years after and three years before the entrepreneur begins to participate in politics. $* * *, * *$ and $*$ denote significance for the difference between the two sample groups at $1 \%$, $5 \%$, and $10 \%$ respectively.

\begin{tabular}{|c|c|c|c|c|c|c|c|c|}
\hline & \multicolumn{5}{|c|}{ Political Participation Sample } & \multicolumn{3}{|c|}{ No Political Participation Sample } \\
\hline & $\mathrm{N}$ & Mean & Median & $\begin{array}{l}\text { Std. } \\
\text { Dev. }\end{array}$ & $\mathrm{N}$ & Mean & Median & Std. Dev \\
\hline Growth in assets & 86 & $0.698 * * *$ & $0.665 * * *$ & 0.507 & 612 & 0.303 & 0.294 & 0.601 \\
\hline Growth in sales & 86 & $0.758 * * *$ & $0.693 * * *$ & 0.548 & 612 & 0.277 & 0.352 & 0.839 \\
\hline Growth in earnings & 86 & $0.663 * * *$ & $0.438 * * *$ & 2.241 & 612 & -0.092 & -0.153 & 2.392 \\
\hline Change in ROA & 86 & $-0.003 * * *$ & $-0.007 * * *$ & 0.052 & 612 & -0.122 & -0.015 & 0.249 \\
\hline Change in ROS & 86 & $-0.025 * *$ & $-0.010 * *$ & 0.156 & 612 & -0.096 & -0.027 & 0.465 \\
\hline Change in $\mathrm{ROE}$ & 86 & $0.032 * * *$ & $-0.008 * * *$ & 0.163 & 612 & -0.022 & -0.014 & 0.257 \\
\hline
\end{tabular}




\section{Table 3 Political Participation and Operating Performance (Continued)}

\section{Panel B: Regression Analysis}

This table presents the OLS regression results of the effect of political participation on operating performance. The dependent variables are different measures for growth or change in operating performance. The independent variables include political participation, which equals one if the private firm's controlling entrepreneur begins to participate in politics and zero otherwise; family ownership, measured as the percentage ownership by the controlling family; state ownership, measured as the sum of state ownership among the top 10 shareholders; Tobin's Q, measured as the sum of total market value and total net liabilities divided by total assets; leverage, measured as the ratio of total liabilities over total assets; size, measured as the natural logarithm of total assets. Industry and year dummies are included but not reported. All continuous variables are winsorized at the top and bottom 1\%. T-statistics are given in parentheses and computed using heteroskedasticity-robust standard errors clustered by industry and year (Petersen, 2009; Thompson, 2011). ***,**, and * denote significance at the $1 \%, 5 \%$, and $10 \%$ level, respectively.

\begin{tabular}{lcccccc}
\hline & $(1)$ & $(2)$ & $(3)$ & $(4)$ & $(5)$ & $(6)$ \\
& $\begin{array}{c}\text { Growth in } \\
\text { assets }\end{array}$ & $\begin{array}{c}\text { Growth in } \\
\text { sales }\end{array}$ & $\begin{array}{c}\text { Growth in } \\
\text { Earnings }\end{array}$ & $\begin{array}{c}\text { Change in } \\
\text { ROA }\end{array}$ & $\begin{array}{c}\text { Change in } \\
\text { ROS }\end{array}$ & $\begin{array}{c}\text { Change } \\
\text { in ROE }\end{array}$ \\
\hline Political & $0.334^{* * *}$ & $0.359^{* * *}$ & $0.683^{* * *}$ & $0.095^{* * *}$ & $0.071^{* *}$ & $0.052^{* *}$ \\
Participation & $(5.80)$ & $(4.92)$ & $(2.65)$ & $(5.97)$ & $(2.26)$ & $(2.46)$ \\
Family & $0.820^{* * *}$ & $0.935^{* * *}$ & 0.637 & $0.142^{* *}$ & $0.019^{* * *}$ & $0.089^{* *}$ \\
Ownership & $(5.02)$ & $(3.97)$ & $(1.39)$ & $(2.26)$ & $(3.14)$ & $(2.27)$ \\
State & $-0.169^{* *}$ & $-0.238^{*}$ & $-0.081^{*}$ & 0.003 & $-0.337 * * *$ & 0.003 \\
Ownership & $(-2.02)$ & $(-1.93)$ & $(-1.77)$ & $(0.04)$ & $(-3.70)$ & $(0.04)$ \\
Tobin's Q & 0.019 & 0.058 & $1.575^{* *}$ & -0.001 & 0.041 & -0.006 \\
& $(0.68)$ & $(1.43)$ & $(2.26)$ & $(-0.10)$ & $(1.62)$ & $(-0.06)$ \\
Leverage & -0.023 & $-0.098^{*}$ & -1.638 & 0.003 & -0.042 & 0.007 \\
& $(-0.64)$ & $(-1.90)$ & $(-1.86)$ & $(0.21)$ & $(-1.28)$ & $(0.56)$ \\
Size & $0.201 * * *$ & $0.213 * * *$ & -0.654 & $0.032 * *$ & -0.009 & 0.002 \\
& $(6.46)$ & $(5.16)$ & $(-0.82)$ & $(2.30)$ & $(-0.36)$ & $(0.16)$ \\
Intercept & $-4.001 * * *$ & $-4.589 * * *$ & 9.405 & $-0.893 * * *$ & 0.079 & -0.126 \\
& $(-5.68)$ & $(-4.77)$ & $(0.53)$ & $(-2.87)$ & $(0.14)$ & $(-0.44)$ \\
Industry/Yea & Yes & Yes & Yes & Yes & Yes & Yes \\
r & & & & & & \\
Observations & 698 & 698 & 698 & 698 & 698 & 698 \\
Adjusted $R^{2}$ & 0.273 & 0.167 & 0.112 & 0.113 & 0.112 & 0.139 \\
\hline
\end{tabular}




\section{Table 4 Political Participation and Changes in Debt Financing Structure and Debt Maturity Panel A: Descriptive Statistics}

This table presents the descriptive statistics of changes in the debt financing structure change and debt maturity for the political participation sample and no political participation sample. The political participation sample is composed of private firms controlled by private entrepreneurs who begin to participate in politics. The no political participation sample is composed of private firms controlled by private entrepreneurs who do not participate in politics in the same year. The change in debt financing structure (debt maturity) are the difference between the average annual debt financing structure (debt maturity) variables during three years after political participation and that during three years before political participation. Debt financing structure is measured as total debt divided by total assets, or total debt plus accounts payable divided by total assets. Debt maturity is measured as long-term debt divided by total debt, or long-term debt divided by total debt plus accounts payable. All variables are winsorized at top and bottom $1 \%$. ***,** and $*$ denote significance for the difference between the two samples at $1 \%, 5 \%$, and $10 \%$, respectively.

\begin{tabular}{|c|c|c|c|c|c|c|c|c|}
\hline & \multicolumn{4}{|c|}{ Political Participation Sample } & \multicolumn{4}{|c|}{ No Political Participation Sample } \\
\hline & $\mathrm{N}$ & Mean & Median & Std. Dev. & $\mathrm{N}$ & Mean & Median & Std. Dev. \\
\hline $\begin{array}{c}\text { Change in } \\
\text { Total Debt/ Total Assets }\end{array}$ & 86 & $0.018 * * *$ & $0.017 * *$ & 0.086 & 612 & -0.009 & -0.004 & 0.235 \\
\hline $\begin{array}{c}\text { Change in } \\
\text { (Total Debt }+ \text { Accounts } \\
\text { Payable)/ } \\
\text { Total Assets }\end{array}$ & 86 & $0.016^{* * *}$ & $0.015^{*}$ & 0.082 & 612 & -0.006 & -0.002 & 0.192 \\
\hline $\begin{array}{c}\text { Change in } \\
\text { Long-Term Debt/ Total Debt } \\
\text { Change in }\end{array}$ & 86 & $0.025^{* * *}$ & $0.007 * *$ & 0.095 & 612 & -0.015 & 0.000 & 0.260 \\
\hline $\begin{array}{c}\text { Long-Term Debt/ } \\
\text { (Total Debt }+ \text { Accounts } \\
\text { Payable })\end{array}$ & 86 & $0.023^{* * *}$ & $0.005 * *$ & 0.090 & 612 & -0.019 & 0.000 & 0.201 \\
\hline Profitability & 86 & $0.048 * * *$ & $0.049 * * *$ & 0.046 & 612 & 0.011 & 0.026 & 0.109 \\
\hline Collateral & 86 & 0.272 & 0.247 & 0.153 & 612 & 0.249 & 0.221 & 0.174 \\
\hline
\end{tabular}


Table 4 Political Participation and Changes in Debt Financing Structure and Debt Maturity (Continued)

\section{Panel B: Regression Analysis}

This table presents the OLS regression results of the effect of political participation on changes in debt financing structure and debt maturity. The dependent variables are the change in debt financing structure and debt maturity. The independent variables are: political participation, which equals one for the firms controlled by entrepreneurs who start to participate in politics and zero otherwise; family ownership, measured as the percentage ownership by the controlling family; state ownership, measured as the sum of state ownership in the top 10 shareholders; Tobin's Q, measured as the sum of total market value and total net liabilities divided by total assets; leverage, measured as the ratio of total liabilities to total assets; size, measured as the natural logarithm of total assets; profitably, measured as the ratio of earnings to total assets; and collateral, measured as the ratio of total net fixed assets to total assets. Industry and year dummies are included but not reported. All continuous variables are winsorized at the top and bottom $1 \%$. $T$-statistics are given in parentheses and computed using heteroskedasticity-robust standard errors clustered by industry and year (Petersen, 2009; Thompson, 2011). ${ }^{* * *},{ }^{* *}$, and ${ }^{*}$ denote significance at the $1 \%, 5 \%$, and $10 \%$ level, respectively.

\begin{tabular}{lcccc}
\hline & $\begin{array}{c}(1) \\
\text { Change in } \\
\text { Total Debt/ } \\
\text { Total Assets }\end{array}$ & $\begin{array}{c}(2) \\
\text { Change in } \\
\text { (Total Debt } \\
\text { Accounts Payable) } \\
\text { Total Assets }\end{array}$ & $\begin{array}{c}(3) \\
\text { Change in } \\
\text { Long Term- } \\
\text { Debt / Total } \\
\text { Assets }\end{array}$ & $\begin{array}{c}(4) \\
\text { Cong Term-Debt/ } \\
\text { (Total Debt + } \\
\text { Accounts Payable) }\end{array}$ \\
\hline Political & $0.025^{* * *}$ & $0.022^{* * *}$ & $0.031^{* * *}$ & $0.036^{* * *}$ \\
Participation & $(4.45)$ & $(4.65)$ & $(5.37)$ & $(4.09)$ \\
Family & $0.033^{* *}$ & $0.049^{* * *}$ & $0.224^{* *}$ & $0.170^{* * *}$ \\
Ownership & $(2.32)$ & $(2.89)$ & $(2.59)$ & $(2.67)$ \\
State & -0.043 & -0.030 & $-0.024^{* * *}$ & $-0.011^{* *}$ \\
Ownership & $(-0.48)$ & $(-0.41)$ & $(-3.24)$ & $(-2.14)$ \\
Tobin's Q & -0.015 & -0.013 & 0.006 & 0.008 \\
& $(-0.98)$ & $(-1.03)$ & $(0.66)$ & $(1.21)$ \\
Leverage & -0.065 & -0.052 & 0.001 & -0.010 \\
Size & $(-1.05)$ & $(-1.13)$ & $(0.04)$ & $(-0.61)$ \\
& 0.006 & 0.003 & $0.024 *$ & $0.017^{*}$ \\
Profitability & $(0.43)$ & $(0.25)$ & $(1.87)$ & $(1.73)$ \\
& $-0.310^{* *}$ & $-0.253^{* *}$ & 0.002 & 0.021 \\
Collateral & $(-2.29)$ & $(-2.33)$ & $(0.02)$ & $(0.28)$ \\
Intercept & 0.002 & 0.004 & $0.150^{* *}$ & $0.136^{* * *}$ \\
Industry/Yea & $(0.03)$ & $(0.09)$ & $(2.38)$ & $(2.64)$ \\
r & 0.068 & 0.102 & -0.509 & -0.343 \\
Observations & $(0.23)$ & $(0.42)$ & $(-1.80)$ & $(-1.60)$ \\
Adjusted $R^{2}$ & Yes & Yes & Yes & Yes \\
\hline
\end{tabular}




\section{Table 5 Political Participation and Tax Burden Change \\ Panel A: Descriptive Statistics}

This table reports the descriptive statistics of tax burden change for the political participation sample and the no political participation sample. The political participation sample is composed of private firms controlled by private entrepreneurs who begin to participate in politics. The no political participation sample is composed of private firms controlled by private entrepreneurs who do not participate in politics in the same year. The change in tax burden is the difference between the average annual ETR1 (or ETR2/ETR3) during the three years after the entrepreneur begins to participate in politics and the average annual during the three years before that event. ETR1 is defined as (tax expense-deferred tax expense)/EBIT, ETR2 is defined as tax expense/EBIT, and ETR3 is defined as tax expense/total profit. Capital intensity is defined as fixed net assets/total assets. Inventory intensity is defined as inventory/total assets. Profitability is defined as earnings/total assets. All variables are winsorized at the top and bottom $1 \%$. ***,**, and $*$ denote significance for the difference between the two samples at $1 \%$, $5 \%$, and $10 \%$, respectively.

\begin{tabular}{|c|c|c|c|c|c|c|c|c|}
\hline & \multicolumn{5}{|c|}{ Political Participation Sample } & \multicolumn{3}{|c|}{ No Political Participation Sample } \\
\hline & $\mathrm{N}$ & Mean & Median & Std. Dev. & $\mathrm{N}$ & Mean & Median & Std. Dev. \\
\hline Change in ETR1 & 86 & $-0.026^{* *}$ & $-0.020 * *$ & 0.068 & 612 & -0.005 & 0.009 & 0.201 \\
\hline Change in ETR2 & 86 & $-0.031 * * *$ & $-0.032 * *$ & 0.080 & 612 & -0.003 & 0.002 & 0.115 \\
\hline Change in ETR3 & 86 & $-0.012 * *$ & $-0.017^{*}$ & 0.071 & 612 & 0.003 & 0.011 & 0.157 \\
\hline Capital intensity & 86 & 0.272 & 0.247 & 0.153 & 612 & 0.249 & 0.221 & 0.174 \\
\hline Inventory intensity & 86 & 0.162 & 0.120 & 0.147 & 612 & 0.179 & 0.130 & 0.166 \\
\hline Profitability & 86 & $0.048 * * *$ & $0.049 * * *$ & 0.046 & 612 & 0.011 & 0.026 & 0.109 \\
\hline
\end{tabular}




\section{Table 5 Political Participation and Tax Burden Change (Continued)}

\section{Panel B: Regression Analysis}

This table reports the OLS regression results of the effect of political participation on tax burden change. The dependent variable is the change in tax burden, measured as the change in ETR1, ETR2, and ETR3, respectively. The independent variables are: political participation, which equals one for the private firms whose entrepreneurs begin to participate in politics and zero otherwise; family ownership, measured as the percentage ownership by the controlling family; state ownership, measured as the sum of state ownership among the top 10 shareholders; Tobin's Q, measured as the sum of total market valuation of equities and total net liabilities divided by total assets; leverage, measured as the ratio of total liabilities over total assets; size, measured as natural logarithm of total assets; capital intensity, defined as fixed net assets/total assets; Inventory intensity, defined as inventory/total assets; profitability, defined as earnings/total assets. Industry and year dummies are included but not reported. All continuous variables are winsorized at the top and bottom 1\%. $T$-statistics are given in parentheses and computed using heteroskedasticity-robust standard errors clustered by industry and year (Petersen, 2009; Thompson, 2011). ***,**, and $*$ denote significance at the $1 \%, 5 \%$, and $10 \%$, respectively.

\begin{tabular}{lccc}
\hline & $(1)$ & $(2)$ & $(3)$ \\
& Change in ETR1 & Change in ETR2 & Change in ETR3 \\
\hline Political Participation & $-0.020^{* *}$ & $-0.027^{* * *}$ & $-0.014^{* *}$ \\
& $(-2.12)$ & $(-2.89)$ & $(-2.30)$ \\
Family Ownership & $-0.037^{*}$ & $-0.055^{*}$ & $-0.002^{* *}$ \\
& $(-1.85)$ & $(-1.74)$ & $(-2.04)$ \\
State Ownership & 0.016 & 0.008 & 0.019 \\
& $(0.23)$ & $(0.18)$ & $(0.34)$ \\
Tobin's Q & $0.009^{*}$ & 0.003 & 0.006 \\
& $(1.65)$ & $(1.16)$ & $(1.49)$ \\
Leverage & $-0.043^{* *}$ & 0.001 & -0.005 \\
& $(-2.09)$ & $(0.12)$ & $(-0.46)$ \\
Size & -0.002 & $-0.011^{*}$ & -0.003 \\
& $(-0.18)$ & $(-1.78)$ & $(-0.49)$ \\
Capital intensity & $0.116^{* *}$ & 0.042 & -0.019 \\
& $(1.99)$ & $(1.34)$ & $(-0.48)$ \\
Inventory intensity & $0.134^{* *}$ & $0.060^{*}$ & 0.049 \\
& $(2.08)$ & $(1.78)$ & $(1.20)$ \\
Profitability & 0.070 & $0.138^{* * *}$ & $0.210^{* * *}$ \\
& $(0.95)$ & $(3.14)$ & $(3.53)$ \\
Intercept & -0.085 & 0.148 & 0.044 \\
& $(-0.34)$ & $(1.16)$ & $(0.29)$ \\
Industry/ Year & Yes & Yes & Yes \\
Observations & 698 & 698 & 698 \\
Adjusted $R^{2}$ & 0.148 & 0.161 & 0.141 \\
\hline
\end{tabular}




\section{Table 6 Political Participation and Government Subsidy Change \\ Panel A: Descriptive Statistics}

This table reports the descriptive statistics of changes in government subsidy for the political participation sample and the no political participation sample. The political participation sample is composed of private firms controlled by private entrepreneurs who begin to participate in politics. The no political participation sample is composed of private firms controlled by private entrepreneurs who do not participate in politics in the same year. The change in government subsidy 1 (or government subsidy2/ government subsidy3) is the difference between average annual government subsidies during three years after the entrepreneur begins to participate in politics and average annual government subsidies during the three years before the event. Government subsidy1 is defined as total government subsidies/EBIT, government subsidy2 is defined as total government subsidies/earnings, and government subsidy3 is defined as total government subsidies/sales. All variables are winsorized at the top and bottom $1 \%$. ***,**, and * denote significance for the difference between two samples at $1 \%, 5 \%$, and $10 \%$, respectively.

\begin{tabular}{|c|c|c|c|c|c|c|c|c|}
\hline & \multicolumn{4}{|c|}{ Political Participation Sample } & \multicolumn{4}{|c|}{ No Political Participation Sample } \\
\hline & $\mathrm{N}$ & Mean & Median & Std. Dev. & $\mathrm{N}$ & Mean & Median & $\begin{array}{l}\text { Sta. } \\
\text { Dev. }\end{array}$ \\
\hline $\begin{array}{l}\text { Change in government } \\
\text { subsidy } 1\end{array}$ & 86 & $0.046^{* *}$ & $0.045 * * *$ & 0.209 & 612 & -0.005 & -0.031 & 0.122 \\
\hline $\begin{array}{l}\text { Change in government } \\
\text { subsidy } 2\end{array}$ & 86 & $0.062 * * *$ & $0.050 * * *$ & 0.168 & 612 & -0.017 & -0.028 & 0.137 \\
\hline $\begin{array}{l}\text { Change in government } \\
\text { subsidy } 3\end{array}$ & 86 & $0.004 * * *$ & $0.002 * * *$ & 0.004 & 612 & -0.008 & -0.009 & 0.007 \\
\hline
\end{tabular}




\section{Table 6 Political Participation and Government Subsidy Change (Continued) Panel B: Regression Analysis}

This table reports the OLS regression results of the effect of political participation on the change in government subsidies. The dependent variables are change in government subsidy, proxied by the change in government subsidy1, government subsidy2, and government subsidy3, respectively. The independent variables are: political participation, which equals one for the private firms whose entrepreneurs begin to participate in politics and zero otherwise; family ownership, measured as the percentage ownership by the controlling family; state ownership, measured as the sum of state ownership among the top 10 shareholders; Tobin's Q, measured as the sum of total market valuation of equities and total net liabilities divided by total assets; leverage, measured as the ratio of total liabilities over total assets; size, measured as the natural logarithm of total assets; profitability, defined as earnings/total assets. Industry and year dummies are included but not reported. All continuous variables are winsorized at top and bottom $1 \%$. $T$ statistics are given in parentheses and computed using heteroskedasticity-robust standard errors clustered by industry and year (Petersen, 2009; Thompson, 2011). ***,**, and $*$ denote significance at the $1 \%, 5 \%$, and $10 \%$, respectively.

\begin{tabular}{lccc}
\hline & $\begin{array}{c}(1) \\
\text { Change in } \\
\text { government } \\
\text { subsidy1 }\end{array}$ & $\begin{array}{c}(2) \\
\text { Change in } \\
\text { government } \\
\text { subsidy } 2\end{array}$ & $\begin{array}{c}(3) \\
\text { Change in } \\
\text { government } \\
\text { subsidy3 }\end{array}$ \\
\hline Political Participation & $0.047^{* *}$ & $0.070^{* * *}$ & $0.003^{* * *}$ \\
Family Ownership & $(2.41)$ & $(2.69)$ & $(8.12)$ \\
State Ownership & $0.022^{*}$ & 0.090 & $0.002^{* *}$ \\
& $(1.93)$ & $(1.54)$ & $(2.41)$ \\
Tobin's Q & $-0.052^{*}$ & -0.041 & -0.001 \\
& $(-1.70)$ & $(-0.38)$ & $(-0.99)$ \\
Leverage & -0.003 & 0.009 & -0.005 \\
& $(-1.19)$ & $(0.18)$ & $(-0.96)$ \\
Size & 0.008 & 0.003 & 0.001 \\
& $(1.21)$ & $(0.19)$ & $(0.15)$ \\
Profitability & -0.003 & 0.022 & -0.001 \\
& $(-0.60)$ & $(1.20)$ & $(-1.00)$ \\
Intercept & $-0.141^{* *}$ & $-0.286^{* *}$ & $-0.002^{*}$ \\
& $(-1.99)$ & $(-2.17)$ & $(-1.82)$ \\
Industry/ Year & 0.052 & -0.502 & -0.004 \\
Observations & $(0.48)$ & $(-1.29)$ & $(-1.35)$ \\
Adjusted $R^{2}$ & Yes & Yes & Yes \\
\hline & 698 & 698 & 698 \\
& 0.082 & 0.112 & 0.133 \\
\hline
\end{tabular}




\section{Table 7. Political Participation and Regulated Industry Entry}

\section{Panel A. Descriptive Statistics}

This table reports the descriptive statistics of regulated industry entry through M\&A transactions during the three years after entrepreneurial political participation. The political participation sample is composed of private firms controlled by private entrepreneurs who begin to participate in politics. The no political participation sample is composed of private firms controlled by private entrepreneurs who do not participate in politics in the same year. Regulated industry is equal to 1 if the firm enters a regulated industry during the three years after entrepreneurial political participation and 0 otherwise.

\begin{tabular}{|c|c|c|c|c|c|c|c|c|}
\hline & \multicolumn{4}{|c|}{ Political Participation Sample } & \multicolumn{4}{|c|}{ No Political Participation Sample } \\
\hline & $\mathrm{N}$ & Mean & Median & Std. Dev. & $\mathrm{N}$ & Mean & Median & $\begin{array}{l}\text { Std. } \\
\text { Dev. }\end{array}$ \\
\hline Regulated Industry & 86 & $0.244 * * *$ & $0 * * *$ & 0.432 & 612 & 0.062 & 0 & 0.241 \\
\hline
\end{tabular}




\section{Table 7 Political Participation and Regulated Industry Entry (Continued)}

\section{Panel B: Regression Analysis}

This table reports the logistic regression result focusing on the effects political participation on regulated industry entry through M\&A transactions by entrepreneurial firms. The dependent variable is a regulated industry entry dummy that is equal to 1 if it enters a regulated industry and 0 otherwise in the three years after entrepreneurial political participation. The independent variables include Political Participation, which equals one for firms controlled by entrepreneurs who begin to participate in politics and zero otherwise; The independent variables are: political participation, which equals one for the firm that the entrepreneur begins to participate in politics and zero otherwise; family ownership, measured as the percentage ownership by the controlling family; state ownership, measured as the sum of state ownership among the top 10 shareholders; Tobin's Q, measured as the sum of total market value and total net liabilities divided by total assets; leverage, measured as the ratio of total liabilities over total assets; size, measured as the natural logarithm of total assets. Industry and year dummies are included but not reported. All continuous variables are winsorized at the top and bottom $1 \%$. Wald Chi-Square statistics are given in parentheses and computed using heteroskedasticity-robust standard errors clustered by industry and year (Petersen, 2009; Thompson, 2011). ${ }^{* * *},{ }^{* *}$, and $*$ denote significance at the $1 \%, 5 \%$, and $10 \%$ level, respectively.

\section{Regulated Industry Entry}

Political Participation

Family Ownership

State Ownership

Tobin's Q

Leverage

Size

Intercept

Industry/ Year

Observations

Pseudo R2
$1.4858 * * *$

$3.2642 * * *$

0.1476

$4.001 * * *$

(10.93)

Yes

698

0.149 


\section{Table 8 Political Participation and Stock Performance - Controlling for Public Recognition}

This table presents the OLS regression results of the effect of political participation on stock performance. The dependent variables are measured as the buy-and-hold abnormal returns (BHARs) in a window of $[1,36]$ around the month of the beginning of political participation, where the benchmarks are alternatively return in excess of equally weighted all A stock shares index, return in excess of tradable value weighted all A stock shares index, return in excess of Size and B/M matching Portfolios, and return in excess of Size, $\mathrm{B} / \mathrm{M}$ and momentum matching Portfolios in Columns 1 to 4 . The independent variables include Political Participation, which equals one for the firm that the entrepreneur begins to participate in politics and zero otherwise; On the Rich List, equal to one if the entrepreneur is one of the three major lists for wealthy individuals in China: Hurun, New Fortune, and the Forbes List, and zero otherwise; Family ownership, measured as the percentage ownership by the controlling family; State ownership, measured as the sum of state ownership in the top 10 shareholders; Tobin's Q, measured as the sum of total market value and total net liabilities divided by total assets; Leverage, measured as the ratio of total liabilities over total assets; Size, measured as the natural logarithm of total assets. Industry dummy and year dummy are also included but not reported. All continuous variables are winsorized at top and bottom $1 \%$. T-statistics are given in parentheses and computed using heteroskedasticity-robust standard errors clustered by industry and year (Petersen, 2009; Thompson, 2011). ***,**, and * denote significance at the $1 \%, 5 \%$ and $10 \%$ level, respectively.

\begin{tabular}{lcccc}
\hline & $(1)$ & $(2)$ & $(3)$ & $(4)$ \\
& $\begin{array}{c}\text { Return in excess } \\
\text { of equally } \\
\text { weighted all A } \\
\text { Stock Shares } \\
\text { index }\end{array}$ & $\begin{array}{c}\text { Return in excess } \\
\text { of tradable value } \\
\text { weighted all A } \\
\text { Stock Shares } \\
\text { index }\end{array}$ & $\begin{array}{c}\text { Return in excess } \\
\text { of Size and B/M } \\
\text { matching } \\
\text { Portfolios }\end{array}$ & $\begin{array}{c}\text { Return in excess } \\
\text { of Size, B/M and } \\
\text { momentum } \\
\text { matching } \\
\text { Portfolios }\end{array}$ \\
\hline Political & $0.182^{* * *}$ & $0.280^{* * *}$ & $0.217^{* *}$ & $0.304^{* * *}$ \\
Participation & $(3.05)$ & $(3.04)$ & $(2.42)$ & $(3.30)$ \\
On the Rich List & $-0.248^{* *}$ & $-0.247^{* *}$ & $-0.108^{* *}$ & $-0.011^{*}$ \\
& $(-2.41)$ & $(-2.03)$ & $(-2.45)$ & $(-1.94)$ \\
Family & $1.319^{* *}$ & $1.333^{* *}$ & $1.261^{* * *}$ & $1.022^{* * *}$ \\
Ownership & $(2.42)$ & $(2.46)$ & $(7.09)$ & $(5.18)$ \\
State Ownership & -0.274 & -0.276 & -0.131 & -0.013 \\
& $(-0.73)$ & $(-0.74)$ & $(-0.62)$ & $(-0.06)$ \\
Tobin's Q & 0.065 & 0.055 & 0.026 & 0.037 \\
& $(1.10)$ & $(0.92)$ & $(1.32)$ & $(1.47)$ \\
Leverage & $-0.306^{*}$ & $-0.311^{*}$ & $-0.066^{*}$ & -0.042 \\
& $(-1.72)$ & $(-1.74)$ & $(-1.91)$ & $(-1.10)$ \\
Size & -0.084 & -0.071 & -0.059 & -0.016 \\
& $(-1.13)$ & $(-1.06)$ & $(-0.30)$ & $(-0.55)$ \\
Intercept & -1.866 & -1.151 & $-1.778^{* * *}$ & 0.135 \\
& $(-1.14)$ & $(-0.71)$ & $(-3.26)$ & $(0.22)$ \\
Industry/Year & Yes & Yes & Yes & Yes \\
Observations & 698 & 698 & 698 & 698 \\
Adjusted $R^{2}$ & 0.231 & 0.216 & 0.236 & 0.228 \\
\hline
\end{tabular}


Table 9 Political Participation and Operating Performance - Controlling for Public Recognition

This table presents the OLS regression results of the effect of political participation on operating performance. The dependent variables are different measures for growth or change in operating performance. The independent variables include Political Participation, which equals one if the private firm's entrepreneur begins to participate in politics and zero otherwise; On the Rich List, equal to one if the entrepreneur is one of the three major lists for wealthy individuals in China: Hurun, New Fortune, and the Forbes List, and zero otherwise; Family ownership, measured as the percentage ownership by the controlling family; State ownership, measured as the sum of state ownership in the top 10 shareholders; Tobin's Q, measured as the sum of total market value and total net liabilities divided by total assets; Leverage, measured as the ratio of total liabilities over total assets; Size, measured as natural logarithm of total assets. Industry dummy and year dummy are also included but not reported. All continuous variables are winsorized at top and bottom 1\%. T-statistics are given in parentheses and computed using heteroskedasticity-robust standard errors clustered by industry and year (Petersen, 2009; Thompson, 2011). ***,**, and * denote significance at the $1 \%, 5 \%$ and $10 \%$ level, respectively.

\begin{tabular}{lcccccc}
\hline & $\begin{array}{c}(1) \\
\text { Growth in } \\
\text { assets }\end{array}$ & $\begin{array}{c}(2) \\
\text { Growth in } \\
\text { sales }\end{array}$ & $\begin{array}{c}\text { Growth in } \\
\text { Earnings }\end{array}$ & $\begin{array}{c}\text { Change } \\
\text { in ROA }\end{array}$ & $\begin{array}{c}(5) \\
\text { Change in } \\
\text { ROS }\end{array}$ & $\begin{array}{c}(6) \\
\text { Change } \\
\text { in ROE }\end{array}$ \\
\hline Political & $0.325^{* * *}$ & $0.343^{* * *}$ & $0.589^{* * *}$ & $0.117^{* * *}$ & $0.065^{* *}$ & $0.051^{* *}$ \\
Participation & $(5.57)$ & $(4.74)$ & $(2.93)$ & $(5.77)$ & $(2.50)$ & $(2.23)$ \\
On the Rich & 0.015 & -0.008 & -0.248 & -0.013 & $-0.092^{* *}$ & -0.010 \\
List & $(0.30)$ & $(-0.12)$ & $(-1.41)$ & $(-0.47)$ & $(-2.04)$ & $(-0.37)$ \\
Family & $0.820^{* * *}$ & $0.858^{* * *}$ & 0.396 & $0.175^{* *}$ & -0.021 & 0.104 \\
Ownership & $(4.82)$ & $(3.86)$ & $(1.63)$ & $(2.13)$ & $(-0.12)$ & $(1.25)$ \\
State & -0.127 & -0.232 & $-0.085^{*}$ & 0.028 & $-0.427^{* *}$ & 0.004 \\
Ownership & $(-0.79)$ & $(-0.87)$ & $(-1.73)$ & $(0.23)$ & $(-2.41)$ & $(0.06)$ \\
Tobin's Q & 0.010 & $0.061^{*}$ & $1.661^{* *}$ & -0.006 & $0.060^{*}$ & -0.002 \\
& $(0.39)$ & $(1.68)$ & $(2.29)$ & $(-0.34)$ & $(1.83)$ & $(-0.17)$ \\
Leverage & -0.011 & $-0.093^{* *}$ & $-1.744 *$ & 0.010 & -0.060 & 0.012 \\
& $(-0.33)$ & $(-2.06)$ & $(-1.91)$ & $(0.45)$ & $(-1.40)$ & $(0.75)$ \\
Size & $0.186^{* * *}$ & $0.195^{* * *}$ & -0.421 & $-0.038^{* *}$ & -0.019 & -0.002 \\
& $(6.40)$ & $(5.07)$ & $(-0.51)$ & $(-2.03)$ & $(-0.55)$ & $(-0.11)$ \\
Intercept & $-3.910^{* * *}$ & $-4.251^{* * *}$ & -3.404 & $-0.141^{* * *}$ & 0.019 & $-0.150(-$ \\
& $(-6.13)$ & $(-4.90)$ & $(-0.19)$ & $(-2.81)$ & $(0.02)$ & $0.46)$ \\
Industry/Year & Yes & Yes & Yes & Yes & Yes & Yes \\
Observations & 698 & 698 & 698 & 698 & 698 & 698 \\
Adjusted $R^{2}$ & 0.277 & 0.154 & 0.119 & 0.113 & 0.125 & 0.041 \\
\hline
\end{tabular}


Table 10 Disentangling Political Rent Seeking and Public recognition

This table presents the ordinary least square results of the effects of political participation and local institutions on firm performance, alternatively measured as the buy-and-hold abnormal returns (BHARs) in a window of $[1,36]$ around the month of the beginning of political participation, where the benchmarks is the Size, B/M and momentum matching portfolios in Columns 1, 3, and 5, and the change in return on sales (ROS), calculated as the difference between the average annual ROS during the three years after and three years before the entrepreneur begins to participate in politics in Columns 2, 4, and 6. Institutions equals one if a firm's headquarter is located in a region with marketization index below median, and zero otherwise when it is defined according to the NERI Index of marketization in Columns 1 and 2. Institutions equals one if a firm's headquarter is located in a region with property protection index below median, and zero otherwise when it is defined according to World Bank(2006) survey in Columns 3 and 4. Institutions equals one if a firm's headquarter is located in a region with real GDP per capita is below median, and zero otherwise in Columns 5 and 6.

Other independent variables include Political Participation, which equals one if the private firm's entrepreneur begins to participate in politics and zero otherwise; the interaction of Political Participation and Institution; Family ownership, measured as the percentage ownership by the controlling family; State ownership, measured as the sum of state ownership in the top 10 shareholders; Tobin's Q, measured as the sum of total market value and total net liabilities divided by total assets; Leverage, measured as the ratio of total liabilities over total assets; Size, measured as natural logarithm of total assets. Industry dummy and year dummy are also included but not reported. All continuous variables are winsorized at top and bottom 1\%. T-statistics are given in parentheses and computed using heteroskedasticity-robust standard errors clustered by industry and year (Petersen, 2009; Thompson, 2011). ***, **, and * denote significance at the $1 \%, 5 \%$ and $10 \%$ level, respectively. 


\begin{tabular}{|c|c|c|c|c|c|c|}
\hline & \multicolumn{2}{|c|}{ Marketization } & \multicolumn{2}{|c|}{ Property rights } & \multicolumn{2}{|c|}{ Real GDP per capita } \\
\hline & $\begin{array}{c}(1) \\
\text { Return in } \\
\text { excess of Size, } \\
\mathrm{B} / \mathrm{M} \text { and } \\
\text { momentum } \\
\text { matching } \\
\text { Portfolios }\end{array}$ & $\begin{array}{c}(2) \\
\text { Change } \\
\text { in } \\
\text { ROS }\end{array}$ & $\begin{array}{c}(3) \\
\text { Return in } \\
\text { excess of Size, } \\
\text { B/M and } \\
\text { momentum } \\
\text { matching } \\
\text { Portfolios }\end{array}$ & $\begin{array}{c}(4) \\
\text { Change } \\
\text { in } \\
\text { ROS }\end{array}$ & $\begin{array}{c}(5) \\
\text { Return in excess of } \\
\text { Size, B/M and } \\
\text { momentum } \\
\text { matching Portfolios }\end{array}$ & $\begin{array}{l}\text { (6) } \\
\text { Change } \\
\text { in } \\
\text { ROS }\end{array}$ \\
\hline $\begin{array}{l}\text { Political } \\
\text { participation }\end{array}$ & $\begin{array}{c}0.174 * * * \\
(3.22)\end{array}$ & $\begin{array}{c}0.042 * * \\
(2.05)\end{array}$ & $\begin{array}{c}0.135 * * * \\
(3.77)\end{array}$ & $\begin{array}{l}0.050 \\
(0.97)\end{array}$ & $\begin{array}{c}0.203 * * * \\
(2.97)\end{array}$ & $\begin{array}{l}0.046^{*} \\
(1.76)\end{array}$ \\
\hline Institutions & $\begin{array}{l}-0.097 \\
(-1.03)\end{array}$ & $\begin{array}{l}-0.008 \\
(-1.17)\end{array}$ & $\begin{array}{l}-0.089 \\
(-0.72)\end{array}$ & $\begin{array}{l}-0.019 * \\
(-1.78)\end{array}$ & $\begin{array}{l}-0.048 \\
(-1.21)\end{array}$ & $\begin{array}{l}-0.021 \\
(-0.69)\end{array}$ \\
\hline $\begin{array}{l}\text { Political } \\
\text { participation* } \\
\text { Institutions }\end{array}$ & $\begin{array}{c}0.235 * * * \\
(3.17)\end{array}$ & $\begin{array}{c}0.034 * * \\
(2.29)\end{array}$ & $\begin{array}{c}0.219 * * * \\
(2.90)\end{array}$ & $\begin{array}{c}0.043 * * * \\
(3.36)\end{array}$ & $\begin{array}{c}0.177 * * * \\
(3.25)\end{array}$ & $\begin{array}{c}0.038 * * * \\
(4.75)\end{array}$ \\
\hline $\begin{array}{l}\text { Family } \\
\text { Ownership }\end{array}$ & $\begin{array}{c}1.206 * * * \\
(4.79)\end{array}$ & $\begin{array}{c}0.014 * * * \\
(3.75)\end{array}$ & $\begin{array}{c}1.013 * * * \\
(5.70)\end{array}$ & $\begin{array}{c}0.021 * * \\
(2.23)\end{array}$ & $\begin{array}{c}0.916^{* * *} \\
(4.64)\end{array}$ & $\begin{array}{c}0.024 * * * \\
(3.83)\end{array}$ \\
\hline State Ownership & $\begin{array}{l}-0.128 \\
(-1.37)\end{array}$ & $\begin{array}{c}-0.329 * * * \\
(-3.61)\end{array}$ & $\begin{array}{l}-0.160 \\
(-0.82)\end{array}$ & $\begin{array}{c}-0.305^{* *} \\
(-2.14)\end{array}$ & $\begin{array}{l}-0.107 \\
(-0.85)\end{array}$ & $\begin{array}{c}-0.325 * * * \\
(-3.13)\end{array}$ \\
\hline Tobin's Q & $\begin{array}{c}0.041 \\
(0.87)\end{array}$ & $\begin{array}{l}0.032 \\
(1.13)\end{array}$ & $\begin{array}{c}0.035 \\
(0.73)\end{array}$ & $\begin{array}{l}0.079 * \\
(1.85)\end{array}$ & $\begin{array}{c}0.051 \\
(1.27)\end{array}$ & $\begin{array}{l}0.053 \\
(1.06)\end{array}$ \\
\hline Leverage & $\begin{array}{l}-0.261 \\
(-1.07)\end{array}$ & $\begin{array}{l}-0.056 \\
(-1.41)\end{array}$ & $\begin{array}{l}-0.243^{*} \\
(-1.81)\end{array}$ & $\begin{array}{l}-0.063 \\
(-1.42)\end{array}$ & $\begin{array}{l}-0.248 \\
(-1.15)\end{array}$ & $\begin{array}{l}-0.064 \\
(-1.17)\end{array}$ \\
\hline Size & $\begin{array}{l}-0.032 \\
(-0.89)\end{array}$ & $\begin{array}{l}-0.012 \\
(-1.01)\end{array}$ & $\begin{array}{l}-0.021 \\
(-0.86)\end{array}$ & $\begin{array}{l}-0.013 \\
(-0.74)\end{array}$ & $\begin{array}{l}-0.039 \\
(-1.26)\end{array}$ & $\begin{array}{l}0.012 \\
(0.27)\end{array}$ \\
\hline Intercept & $\begin{array}{c}1.264 \\
(1.36)\end{array}$ & $\begin{array}{c}0.094 * * \\
(1.97)\end{array}$ & $\begin{array}{c}1.542 \\
(1.24)\end{array}$ & $\begin{array}{l}-0.081 \\
(-0.27)\end{array}$ & $\begin{array}{l}0.983 * \\
(1.72)\end{array}$ & $\begin{array}{l}0.042 \\
(0.66)\end{array}$ \\
\hline $\begin{array}{l}\text { Industry/Year } \\
\text { Observations } \\
\text { Adjusted } R^{2}\end{array}$ & $\begin{array}{c}\text { Yes } \\
698 \\
0.233\end{array}$ & $\begin{array}{c}\text { Yes } \\
698 \\
0.119\end{array}$ & $\begin{array}{c}\text { Yes } \\
698 \\
0.227\end{array}$ & $\begin{array}{c}\text { Yes } \\
698 \\
0.118\end{array}$ & $\begin{array}{c}\text { Yes } \\
698 \\
0.230\end{array}$ & $\begin{array}{c}\text { Yes } \\
698 \\
0.114\end{array}$ \\
\hline
\end{tabular}

